Review

\title{
Production of Flocculants, Adsorbents, and Dispersants from Lignin
}

\author{
Jiachuan Chen ${ }^{1}$, Armin Eraghi Kazzaz ${ }^{2}$, Niloofar AlipoorMazandarani ${ }^{2}$, \\ Zahra Hosseinpour Feizi ${ }^{2}$ and Pedram Fatehi ${ }^{1,2, *}$
}

1 Key Laboratory of Pulp and Paper Science and Technology of Ministry of Education, Qilu University of Technology (Shandong Academy of Sciences), Jinan 250353, China; chenjc@qlu.edu.cn

2 Chemical Engineering Department, Lakehead University, 955 Oliver Road, Thunder Bay, ON P7B 5E1, Canada; aeraghi@lakeheadu.ca (A.E.K.); nalipoor@lakeheadu.ca (N.A.); zhossein@lakeheadu.ca (Z.H.F.)

* Correspondence: pfatehi@lakeheadu.ca; Tel.: +807-343-8697; Fax: +807-346-7943

Academic Editors: Charles $\mathrm{Xu}$ and Michael Paleologou

Received: 11 March 2018; Accepted: 6 April 2018; Published: 10 April 2018

\begin{abstract}
Currently, lignin is mainly produced in pulping processes, but it is considered as an under-utilized chemical since it is being mainly used as a fuel source. Lignin contains many hydroxyl groups that can participate in chemical reactions to produce value-added products. Flocculants, adsorbents, and dispersants have a wide range of applications in industry, but they are mainly oil-based chemicals and expensive. This paper reviews the pathways to produce water soluble lignin-based flocculants, adsorbents, and dispersants. It provides information on the recent progress in the possible use of these lignin-based flocculants, adsorbents, and dispersants. It also critically discusses the advantages and disadvantages of various approaches to produce such products. The challenges present in the production of lignin-based flocculants, adsorbents, and dispersants and possible scenarios to overcome these challenges for commercial use of these products in industry are discussed.
\end{abstract}

Keywords: lignin; flocculants; dispersants; chemical reaction; product analysis; biorefining

\section{Introduction}

Greenhouse gas emission is a major driver of global warming; mainly caused by human activities, such as fossil fuel combustion, deforestation, livestock farming, use of synthetic fertilizers, and industrial processes. Contamination of global freshwater systems with industrial chemicals is another crucial problem calling for the generation of nontoxic chemicals and transition to more sustainable processes [1,2]. Currently, many oil-based chemicals are used in industry for a variety of purposes, and unwillingly some will be released to the environment, causing wildlife and environmental issues, consequently. Also, these oil-based chemicals are heavily used in treating water and wastewater systems [3,4]. These commercial materials are mainly expensive, inefficient, and sometimes environmentally unfriendly, raising the need for being replaced by environmentally friendly analogs, such as biomass based value-added products.

Lignin is the most abundant natural aromatic polymer composing 18-35 wt. \% of wood [5,6]. It was estimated that $(5-36) \times 10^{8}$ tons of lignin are produced annually [7]. In woody plants, lignin plays a critical role in providing strength to fiber walls, controlling fluid flow, and protecting against enzymatic degradation [8]. Lignin contains phenylpropanoid units originating from three aromatic alcohol precursors (monolignols), p-coumaryl, coniferyl, and sinapyl alcohols [9]. It was reported that 50 million tons of lignin are produced annually only by the pulping industry; however, the majority of lignin is burned and used as a fuel source, implying that lignin is currently under-utilized $[9,10]$. 
Lignin's physicochemical advantages are classified as: (a) being rich in functional groups; (b) having high adsorption capacity; and (c) having high potential for value-added product production [10]. Interestingly, lignin's renewable, nontoxic, and biodegradable nature allows for its effective valorization into value-added products [11]. The efforts to convert lignin derivatives into sensor components [12], biocomposites [13], biofuels [14,15], and hydrogels [16,17] are currently under development.

Lignosulfonate is a by-product of the sulfite pulping process, providing up to $90 \%$ of commercial lignin with an annual production of around 1.8 million tons [18-23]. The hydrophobicity, water solubility, and negative charge density of lignosulfonate, in addition to its thermal stability, renewability and eco-friendliness [24], make this polymer a promising candidate to be used in industry [21,24]. Kraft lignin is produced via pulping of wood chips using sodium sulfite and sodium hydroxide, while alkali lignin is produced via pulping of wood chips using sodium hydroxide [18-23]. Kraft lignin and alkali lignin are not water soluble at pH 7 in opposition to lignosulfonates [18-23].

Technical lignin's application as a flocculant and dispersant has received a considerable attention [25], which is the focus of this review paper. In this work, the advantages and disadvantages of using lignin for producing flocculants, coagulants, and dispersants are also critically reviewed.

\section{Flocculant}

Flocculants have been extensively used in treating wastewater effluents with the aim of removing colloidal particles from the solutions and suspensions [4,26]. Flocculants aggregate colloidal particles via charge neutralization, patching, and bridging mechanisms as shown in Figure 1. In the charge neutralization mechanism, the charges of colloidal particles are neutralized by adsorption of flocculants, and thus repulsion force existing between adjacent particles is diminished/reduced, which causes these particles to agglomerate via developing van der Waals interaction, for example (Figure 1a). In the patching mechanism, flocculants adsorb on a colloidal particle due to their opposite charges, and they neutralize a part of the particle's surface. Due to their opposite charges, the adsorbed flocculants will act as anchoring points for another adjacent particle for aggregation (Figure 1b). In the bridging mechanism, high molecular weight flocculants adsorb on particles. Due to their large sizes, the flocculants bridge particles and hence generate large flocs (Figure 1c). Although synthetic organic flocculants have been mostly used in industry [27-29], they are non-biodegradable, inefficient, and expensive [30]. Biomass based flocculants can be produced to replace synthetic flocculants. Table 1 classifies different kinds of modified lignin used as flocculants in various fields [31]. In the following sections, the application of lignin-based flocculants in different wastewater treatment systems is described.

a

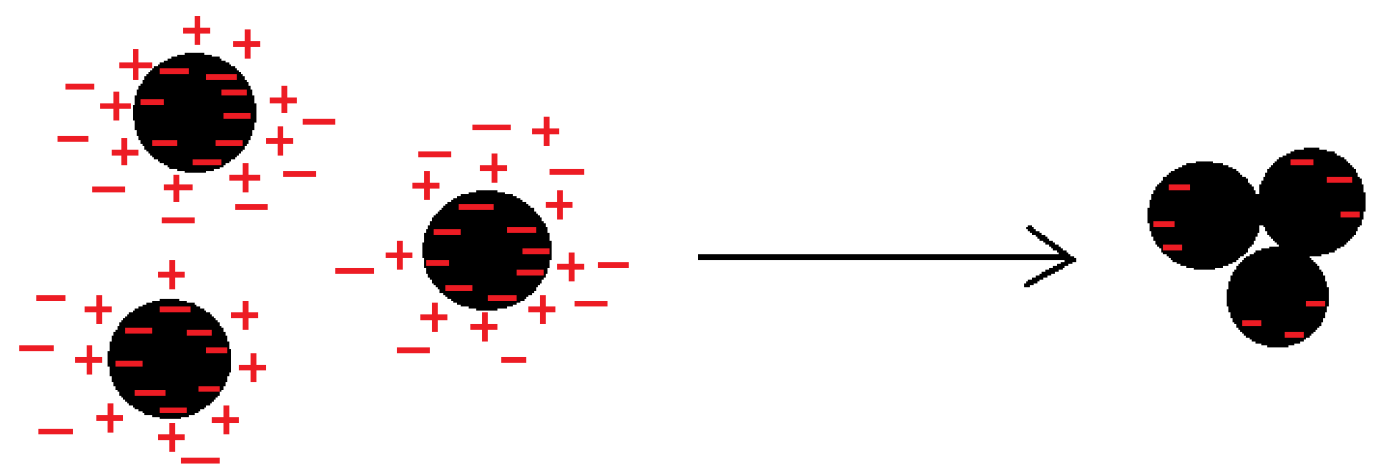

Figure 1. Cont. 
b

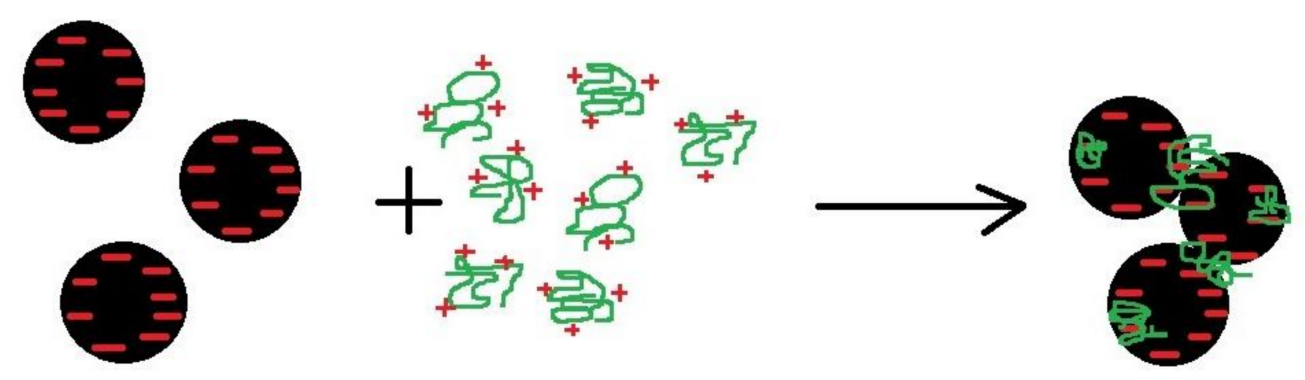

c

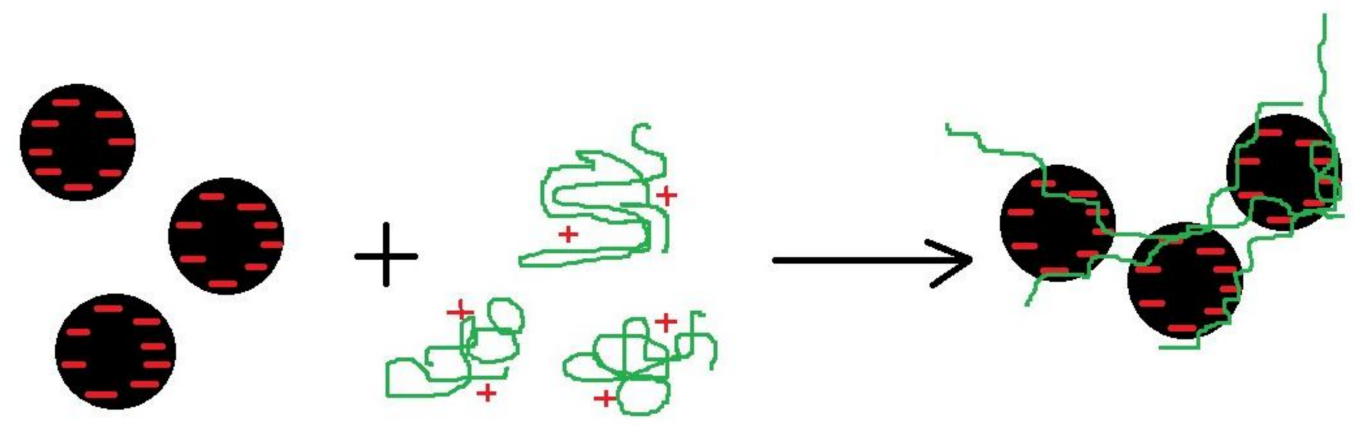

Figure 1. Mechanisms of flocculation: (a) charge neutralization; (b) patching; and (c) bridging.

\subsection{Flocculants for Wastewater Systems}

To remove natural organic substances from wastewater, the most frequently used and economically feasible method is coagulation/flocculation [32]. Generally, hydrophobic and high molecular weight compounds could be removed via coagulation. However, this method is inefficient for removing low molecular weight and hydrophilic compounds from wastewater [33]. To address this problem, $\mathrm{Li}$ and coworkers [34] synthesized a sludge-based flocculant by grafting amine groups onto the organics of sludge (Figure 2). The sludge contained a major portion of lignin, and thus the chemical structure of lignin was considered for describing its reaction mechanisms with other chemicals in Figure 2. The reaction was conducted by reacting sludge with epichlorohydrin and $N, N$-dimethylformamide at a ratio of $1 / 1.6 / 1.6(w / v / v)$ dried sludge/epichlorohydrin/N,N-dimethylformamide at $60-70{ }^{\circ} \mathrm{C}$ for $1 \mathrm{~h}$. Then, ethylenediamine was added to the reactor at the ratio of $1 / 0.4(w / v)$ dried sludge/ethylenediamine and the mixture was treated for another hour. Afterward, triethylamine was reacted with the product under the conditions of $1 / 1.2(w / v)$ dried pulping sludge/triethylamine for two hours at $60-70{ }^{\circ} \mathrm{C}$. The produced amine-crosslinked sludge-based cationic polymer used as a flocculant along with aluminum sulfate (AS) and poly aluminum chloride (PAC) for removing humic acid from a wastewater effluent. The AS and PAC were used for improving the efficiency of flocculation in a dual system. The results showed that the product could be used as a flocculant in this system and its efficiency was $25 \%$ higher under acidic conditions [34]. 


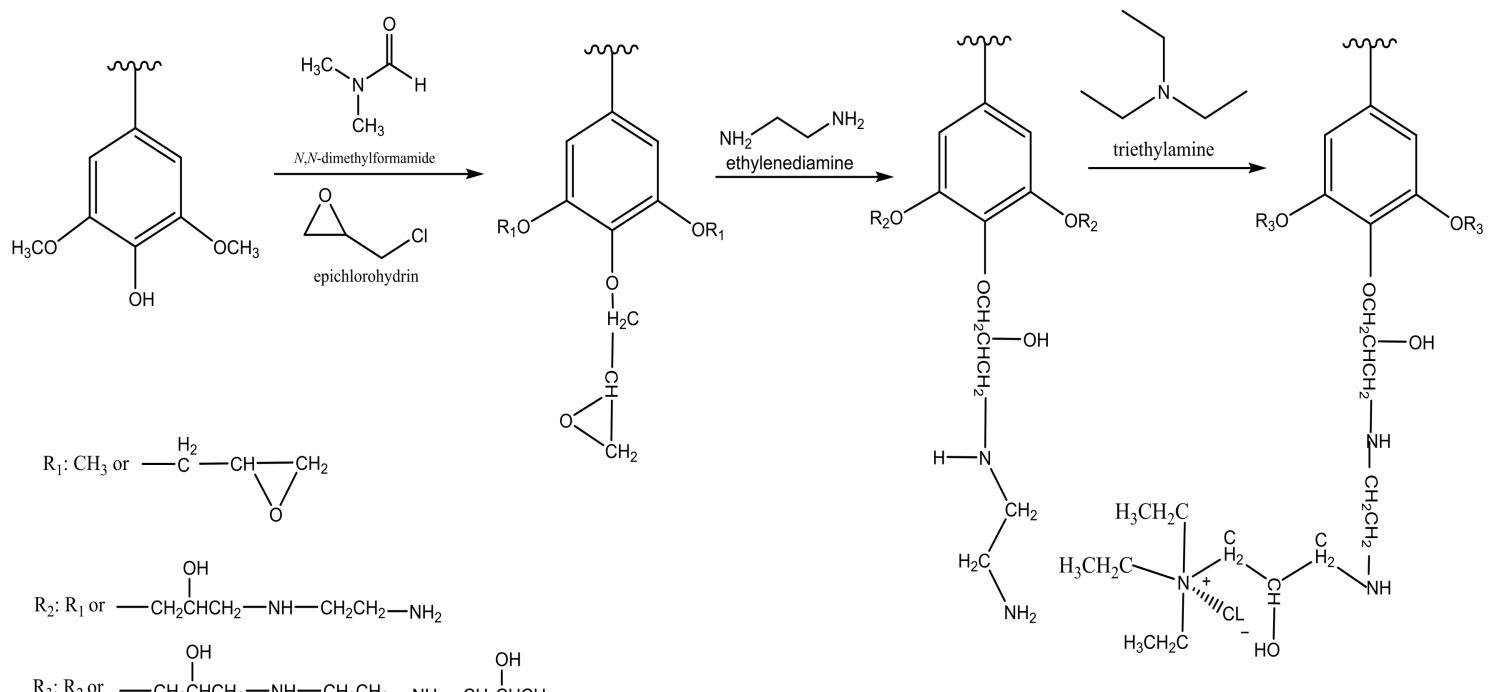

Figure 2. Reaction scheme for producing crosslinked amine-based sludge flocculant [34]. The sludge contained mainly lignin and hence the structure of lignin was selected to represent sludge as the raw material in this reaction.

Table 1. Lignin-based flocculants used in different fields.

\begin{tabular}{|c|c|c|c|c|c|}
\hline Lignin Type & Application & $\begin{array}{l}\text { Charge Density } \\
\text { meq/g }\end{array}$ & $\begin{array}{c}\mathrm{MW} \\
(\mathrm{g} / \mathrm{mol})\end{array}$ & Modification & References \\
\hline Pulping sludge containing lignin & Wastewater & N/A & 510,000 & $\begin{array}{l}\text { Amination with } \\
\text { triethylamine }\end{array}$ & [34] \\
\hline Kraft lignin from black liquor & Dye removal & N/A & N/A & $\begin{array}{c}\text { Grafting trimethyl } \\
\text { quaternary ammonium salt }\end{array}$ & [35] \\
\hline Alkali lignin & Dye removal & N/A & N/A & $\begin{array}{l}\text { Grafting trimethyl } \\
\text { quaternary ammonium salt } \\
\text { and along with sodium } \\
\text { alginate }\end{array}$ & [36] \\
\hline $\begin{array}{l}\text { Thermomechanical pulping lignin } \\
\text { (76 wt. \% lignin) }\end{array}$ & Dye removal & -3.02 & 6270 & Nitric acid oxidation & [37] \\
\hline \multirow{3}{*}{ Hydrolysis lignin } & \multirow{3}{*}{ Dye removal } & +1.79 & 2669 & \multirow{3}{*}{$\begin{array}{l}\text { Dimethylamine-acetone- } \\
\text { formaldehyde copolymer } \\
\text { grafting, Mannich reaction }\end{array}$} & \multirow{3}{*}{ [38] } \\
\hline & & +2.11 & 2762 & & \\
\hline & & +2.55 & 6143 & & \\
\hline $\begin{array}{l}\text { Papermaking sludge ( } 45-50 \mathrm{wt} . \% \\
\text { lignin and 5-10 wt. \% cellulose) }\end{array}$ & Wastewater & N/A & 1000 & $\begin{array}{l}\text { Acrylamide graft } \\
\text { copolymerization }\end{array}$ & {$[39,40]$} \\
\hline Softwood kraft lignin & Dye removal & +1.10 & 21,600 & Cationization with GTMAC & [11] \\
\hline Softwood kraft lignin & Dye removal & -4.61 & 18,300 & $\begin{array}{l}\text { Oxidation and } \\
\text { sulfomethylation }\end{array}$ & [41] \\
\hline
\end{tabular}

N/A: not available.

In another study, the sludge of a pulping process containing $45-50 \mathrm{wt}$. \% lignin and 5-10 wt. \% cellulose was used to produce acrylamide-based polymers in a free radical polymerization system under alkaline $\mathrm{pH}$ (Table 1) [39]. The product of this reaction was used as a flocculant along with polyaluminum chloride (PAC) to treat humic acid solution [40]. However, the poor solubility of the flocculants at a higher $\mathrm{pH}$ was cited as the main problem of this flocculation system.

Lignosulfonate can be used in the production of flocculants. Lignosulfonate has been reported to have the highest molecular weight among all lignin products [21]. Generally, it was suggested that the higher the molecular weight of the polymer, the better its flocculation performance [22]. The water solubility of lignosulfonate has led to its vast utilization as a flocculant in wastewater systems [21]. Table 2 shows lignosulfonate applications as a flocculant in various fields. The charge density and molecular weight of these samples were not reported in these reports. 
Table 2. Lignosulfonate as a flocculant in different areas.

\begin{tabular}{ccc}
\hline Application as a Flocculant & Modification & Reference \\
\hline Wastewater containing furfural & Radiation polymerization with olefins monomers & {$[42]$} \\
oil sands & No modification, but applied along with polyacrylamide-based polymers & {$[43]$} \\
Wastewater & Grafting with acrylamide and chitosan & {$[44]$} \\
\hline
\end{tabular}

Liu and coworkers grafted olefin monomers to lignosulfonate by using radiation graft polymerization and used the resulting natural-based polymers as flocculants for removing furfural from wastewater [42]. In another work, lignosulfonate was used as a flocculant along with a high molecular weight linear polyacrylamide-based polymer for flocculating particles in a mining waste. The dual polymer system having lignosulfonate and polyacrylamide-based polymer at the dosages of 1 and $2.5 \mathrm{~g} / \mathrm{L}$, respectively, was found to be effective as it increased the chord length of the particles from 20 to $145 \mu \mathrm{m}$ for the flocs, while decreasing the number of particle in suspension from 100,000 to 80,000 as determined by focused beam reflectance measurement (FBRM) analysis [43].

Even though lignosulfonate is water soluble [22], there are some barriers in its use: (1) it is less available than kraft lignin worldwide since the kraft pulping process is more common than the sulfite pulping process; (2) its high sulfur content is a limitation for some applications such as polymer synthesis; (3) sulfur removal from lignosulfonate is challenging since it is chemically bonded to lignin; and (4) the sulfite spent liquor containing lignosulfonate contains hemicelluloses, indicating the impurity in the produced lignosulfonate [45].

\subsection{Flocculants for Dye Removal}

Textile effluents contain a significant amount of dyes, which are generally non-biodegradable and have a high level of toxicity and strong color [38]. To treat this source of environmental pollution [46], adsorption, oxidation, hyper-filtration, biodegradation, flocculation, and ozonation processes were considered in the past [47-52]. Inorganic coagulants including aluminum sulfate, ferric chloride, and polyaluminum salts are used as flocculants for dye removal due to their low costs; however, these inorganic coagulants need to be applied in high concentrations, resulting in a large volume of sludge. The use of high concentration of ferric or aluminum ions generally yields a high concentration of salts in the solution after treatment, which has a harmful effect on the ecosystem [38].

Lignin has been aminated (Table 1) for removing anionic dyes from solutions. In a work conducted by Fang and coworkers, a quaternary ammonium salt was grafted onto kraft lignin with a mass ratio of $2 / 1$ of trimethyl quaternary ammonium/lignin at $70{ }^{\circ} \mathrm{C}$ [35]. The modified lignin at $2-3 \mathrm{~g} / \mathrm{L}$ dosage showed $94.02 \%$ removal of Acid Black dye from a $0.1 \mathrm{~g} / \mathrm{L}$ dye concentration in acidic conditions ( $\mathrm{pH} 2-3$ ) [35]. It was also discovered that the aminated lignin could remove $94.91 \%$ of Acid Black ATT $\left(0.1 \mathrm{~g} / \mathrm{L}\right.$ concentration) and $97.11 \%$ of Methylene Blue $\left(0.1 \mathrm{~g} / \mathrm{L}\right.$ concentration) at $30^{\circ} \mathrm{C}$ and $\mathrm{pH} 3$ and 8 , respectively [36]. Kong et al. (2015) grafted glycidyl-trimethylammonium chloride (GTMAC) onto softwood kraft lignin (Table 1) in the molar ratio of $2 / 1$ GTMAC/lignin for $1 \mathrm{~h}$ at $70{ }^{\circ} \mathrm{C}$, in which aminated lignin with the charge density of $1.10 \mathrm{meq} / \mathrm{g}$ was generated [11]. In this reaction, GTMAC reacts with the phenolic group of lignin under alkaline conditions and renders lignin cationically charged and water soluble. The use of this lignin as a flocculant for the removal of Remazol Brilliant Violet (V5), Reactive Black 5 (B5), and Direct Yellow 50 (Y50) (100 mg/L concentration) led to more than $87 \%$ dye removal at the lignin concentrations of 95,235 , and $375 \mathrm{mg} / \mathrm{L}$ for V5, B5, and Y50, respectively [11]. In another study, enzymatically hydrolyzed cornstalk lignin was polymerized via the Mannich reaction with dimethylamine, acetone, and formaldehyde. The addition of 75, 50, and $35 \mathrm{mg} / \mathrm{L}$ of this cationic flocculant in Acid Black, Reactive Red, and Direct Red dyes solutions (100 mg/L) led to $97.1,98.3$, and $99.5 \%$ removals, respectively [11]. He and coworkers reported that a ternary graft copolymer of lignosulfonate-acrylamide-chitosan could be used as a flocculant in wastewater treatment systems. The copolymer was produced with a chitosan/sodium lignosulfonate/acrylamide mass ratio of 1.5/1.5/3 mixed with potassium persulfate/sodium thiosulfate in the mass ratio of $0.05 / 0.05$ and 
reacted for $5 \mathrm{~h}$ at $60^{\circ} \mathrm{C}$. Three different dyes of Reactive Black $5(\mathrm{Rb}-5)$ (neutral), Methyl Orange (MO) (cationic), and Acid Blue 113 (Ab-113) (anionic) were used to simulate textile wastewater and the produced amphoteric copolymer was used as a flocculant in the system. The polymer removed 50, 85 , and $98 \%$ of dyes ( $50 \mathrm{mg} / \mathrm{L}$ concentration) when 335,135 , and $35 \mathrm{mg} / \mathrm{L}$ of the polymer were used for $\mathrm{MO}, \mathrm{Rb}-5$, and Ab-113, respectively. The flocculation mechanism was determined to be charge neutralization in this work [44].

Lignin has also been modified to increase its anionic charge density for removing cationic dyes from solutions. In one study, softwood kraft lignin was oxidized (Table 1) with nitric acid (20 wt. \% based on lignin, $60-100{ }^{\circ} \mathrm{C}$ for $0.5-4 \mathrm{~h}$ ) and then sulfomethylated under the conditions of $1 / 1 \mathrm{~mol} / \mathrm{mol}$ formaldehyde/lignin, $0.5 / 1$ sodium metabisulfite/lignin, and $4 \mathrm{wt}$. \% sodium hydroxide concentration at $60-100{ }^{\circ} \mathrm{C}$ for $1 \mathrm{~h}$. The produced lignin had a charge density of $-4.61 \mathrm{meq} / \mathrm{g}$ and the molecular weight of $18,300 \mathrm{~g} / \mathrm{mol}$, and was able to coagulate $99.1 \%$ of ethyl violet dye ( $200 \mathrm{mg} / \mathrm{L}$ concentration) at a $300 \mathrm{mg} / \mathrm{L}$ dosage [41]. Couch et al. (2016) reported that, thermomechanical lignin-carbohydrate complex (LCC), containing $76 \mathrm{wt}$. \% lignin and $24 \mathrm{wt} . \%$ of hemicellulose, was oxidized (Table 1) with nitric acid under different concentrations of 70 and $30 \mathrm{wt} . \%$ at $60-100{ }^{\circ} \mathrm{C}$ for different times (20-120 min). The oxidized lignin had a charge density of $-3.02 \mathrm{meq} / \mathrm{g}$ and molecular weight of $6270 \mathrm{~g} / \mathrm{mol}$. The use of this product as a flocculant resulted in 70-80 wt. \% of Ethyl Violet and 80-95\% of Basic Blue dye removals from simulated solutions [37]. Generally, the charge density of this modified lignin had a significant impact on their performance since the main driving force for the removal was the charge neutralization mechanism [53].

Effluents of the textile industry may contain salts and have different $\mathrm{pH}$. It was reported that the reduction of $\mathrm{pH}$ improved the efficiency of aminated lignin in dye removal. The presence of salts $\left(\mathrm{NaCl}\right.$ and $\mathrm{NaNO}_{3}$ ) up to $0.05 \mathrm{~mol} / \mathrm{L}$ concentration did not affect their performance significantly [38]. However, $\mathrm{NaCl}$ (at a $3 \mathrm{~g} / \mathrm{L}$ concentration) reduces the efficiency of oxidized lignin in Basic Blue dye removal from $84 \%$ to $77 \%$ [37].

However, the main barrier to produce lignin-based flocculants are the complex and heterogeneous structure of the flocculants [54,55]. Also, lignin obtained from different processes (sulfite, kraft, and organosolv) have different physical and chemical characteristics, thereby affecting their modification processes and product performance [56]. The current challenge in producing lignin-based flocculants is to identify environmentally friendly and cost-effective processes for lignin modification (Table 1) in order to induce flocculants with a high charge density, molecular weight, and hydrophilicity. On the other hand, lignin contains many functional groups such as phenol hydroxyl, methoxy, hydroxy, and carboxy groups [57,58], which makes it feasible to engraft the functional groups to its structure [59].

\section{Adsorbent}

\subsection{Adsorbent for Heavy Metals}

Wastewater from mining operations, fossil fuel combustion, metal plating, and tanneries contain heavy metals and poses environmental concerns [60]. Application of lignin to adsorb these heavy metals from solutions has shown a profound efficiency [61]. A summary of lignin application in metal removal is compiled in Table 3.

Table 3. Lignin potential in heavy metal removal.

\begin{tabular}{cccc}
\hline Material & Adsorbent & Adsorption Capacity & Reference \\
\hline $\mathrm{Pb}(\mathrm{II})$ & Wheat straw lignin & $85 \%$ & {$[62]$} \\
\hline $\begin{array}{c}\mathrm{Cr}(\mathrm{III})+\mathrm{Pb}, \mathrm{Cr}(\mathrm{III})+\mathrm{Cu}, \\
\mathrm{Cr}(\mathrm{III})+\mathrm{Zn}, \mathrm{Cr}(\mathrm{III})+\mathrm{Cd}\end{array}$ & Isolated lignin from black liquor & $\geq 90 \%$ & {$[63]$} \\
\hline $\mathrm{Cr}(\mathrm{VI})$ & Kraft lignin & $33.33 \mathrm{mg} / \mathrm{g}$ & {$[64]$} \\
\hline $\mathrm{Cr}(\mathrm{VI})$ & Alkali lignin & $65 \mathrm{mg} / \mathrm{g}$ & {$[65]$} \\
\hline
\end{tabular}


Table 3. Cont.

\begin{tabular}{cccc}
\hline Material & Adsorbent & Adsorption Capacity & Reference \\
\hline $\mathrm{Cu}+\mathrm{Ni}$ & Kraft lignin & $\begin{array}{c}\geq 0 \% \\
\geq 80 \%\end{array}$ & {$[66]$} \\
$\mathrm{Cu}+\mathrm{Cd}$ & Wheat straw lignin & $100 \%$ & $100 \%$ \\
\hline $\mathrm{Fe}(\mathrm{III})$ & Wheat straw lignin & $35 \mathrm{mg} / \mathrm{g}$ & {$[67]$} \\
$\mathrm{Mn}(\mathrm{III})$ & Alkynylated lignin & $87.4 \mathrm{mg} / \mathrm{g}$ & {$[69]$} \\
\hline $\mathrm{Cu}(\mathrm{II})$ & Aminated/esterified alkali lignin & $120 \mathrm{mg} / \mathrm{g}$ & {$[70]$} \\
\hline $\mathrm{Cd}(\mathrm{II})$ & Aminated sulfomethylated lignin & $\geq 60 \%$ & {$[68]$} \\
\hline $\mathrm{Pb}(\mathrm{II})$ & Fe-Aminated lignin complex & $\geq 60 \%$ & {$[71]$} \\
\hline $\mathrm{Cu}(\mathrm{II})$ & & $80 \%$ & \\
$\mathrm{~Pb}(\mathrm{II})$ & Crosslinked lignocatechol & $100 \%$ & {$[72]$} \\
\hline $\mathrm{PO}{ }_{4}^{2-}$ & & $100 \%$ & {$[15]$} \\
\hline $\mathrm{Al}(\mathrm{III})$ & Lignin-polyaniline & $1556.8 \mathrm{mg} / \mathrm{g}$ & {$[73]$} \\
$\mathrm{Co}(\mathrm{II})$ & Lignin-melamine formaldehyde & $73.2 \mathrm{mg} / \mathrm{g}$ & \\
\hline $\mathrm{La}(\mathrm{III})$ & & & \\
\hline $\mathrm{Ag}{ }^{+}$ & & & \\
\hline $\mathrm{Cu}(\mathrm{II})$ & &
\end{tabular}

Generally, adsorbents have charges and these charges will interact with ions in wastewater via the charge neutralization mechanism. The results of this interaction are the complexation of ions with the adsorbents, as shown in Figure 3. The produced complexes may be removed from wastewater effluents via filtration and/or sedimentation.

Kraft lignin, without modification, has been used as an adsorbent in many simulated wastewater systems. In one report, bonding strength among various ions and kraft lignin was reported to be in the order of $\mathrm{Pb}$ (II) $>\mathrm{Cu}(\mathrm{II})>\mathrm{Cd}$ (II) $>\mathrm{Zn}$ (II) $>\mathrm{Ni}$ (II) [62]. Results demonstrated the higher efficiency of lignin's phenolate group than lignin's carboxylate groups in coagulating metals [62]. In another study, the adsorption of heavy metals on kraft lignin followed the order of $\mathrm{Cr}(\mathrm{VI})>\mathrm{Cd}$ (II) $>\mathrm{Cu}$ (II) $>\mathrm{Zn}$ (II) [66]. As shown in Table 3, lignin had different efficiencies in metal removal as differently sourced lignin contained varied properties originating from wood species and pulping process [62-68].

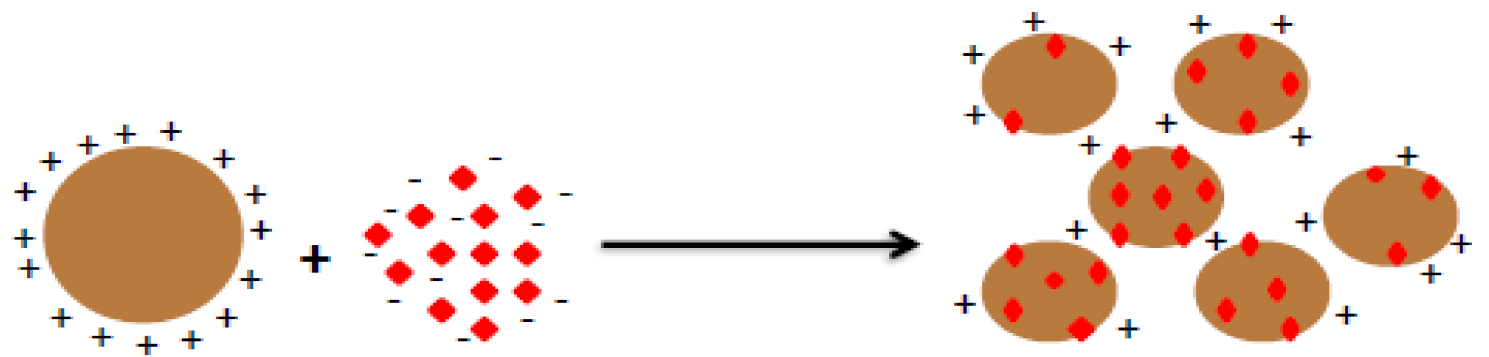

Figure 3. Mechanism of adsorbents in adsorbing ions.

Modification of lignin has also been examined as a means to produce adsorbents for heavy metal removal. One study introduced secondary amino groups on enzymatic hydrolysis lignin's backbone via reacting with poly $\left(\mathrm{N}\right.$-methylaniline, PNMA) for $4 \mathrm{~h}$ at $25^{\circ} \mathrm{C}$ [13]. Introduction of methyl and imino groups onto lignin enhanced electron donating properties of the final product. The product removed silver ions from wastewater. A high silver uptake of $1556.8 \mathrm{mg} / \mathrm{g}$ was reported for this modified lignin. In the past, influence of aminated-Fe lignin complex on $\mathrm{PO}_{4}^{3-}$ uptake from wastewater was studied [71]. First, lignin was aminated by triethylenetetramine in an alkaline solution for $4 \mathrm{~h}$ at $65^{\circ} \mathrm{C}$. Then, aminated lignin was chelated with $\mathrm{FeCl}_{3}$ by stirring for $4 \mathrm{~h}$ at $35^{\circ} \mathrm{C}$ to allow the uptake of $\mathrm{Fe}^{3+}$. When the modified lignin was applied to wastewater system, the phosphate-Fe-lignin complexes 
were formed with the particle size of $452.4 \mathrm{~nm}$. Results reported a maximum $\mathrm{PO}_{4}^{3-}$ removal capacity of $90 \%$. It was confirmed that $\mathrm{Fe}(\mathrm{III})$ was the active site for adsorption, and charge interaction was the main interaction force between phosphate and iron. Another novel modification for alkynylated lignin production was performed through thiol-yne reaction to remove different ions from water [69], as shown in Figure 4. In the first reaction, alkynylated lignin was prepared via reacting lignin and propargyl bromide under alkaline conditions for $2 \mathrm{~h}$ and $75^{\circ} \mathrm{C}$ (Figure 4). In the next reaction, thiol-yne click reaction was conducted on alkynylated lignin, in which 2,2-dimethoxy-2-phenylacetophenone (DMPA) and 1,2,4-triazole-3-thiol monomers were reacted with the modified lignin in tetrahydrofuran under UV radiation. Introduction of thio-triazole units into lignin led to an increased molecular weight of the product $(6756 \mathrm{~g} / \mathrm{mol})$ with an alkynylation degree of $2.47 \mathrm{mmol} / \mathrm{g}$. The produced coagulant exhibited a selective adsorption capacity in the order of $\mathrm{Cd}$ (II) $>\mathrm{Pb}$ (II) $>\mathrm{Cu}$ (II) $>\mathrm{Ni}$ (II) $>\mathrm{Zn}$ (II), which is consistent with what was reported for unmodified lignin [66].

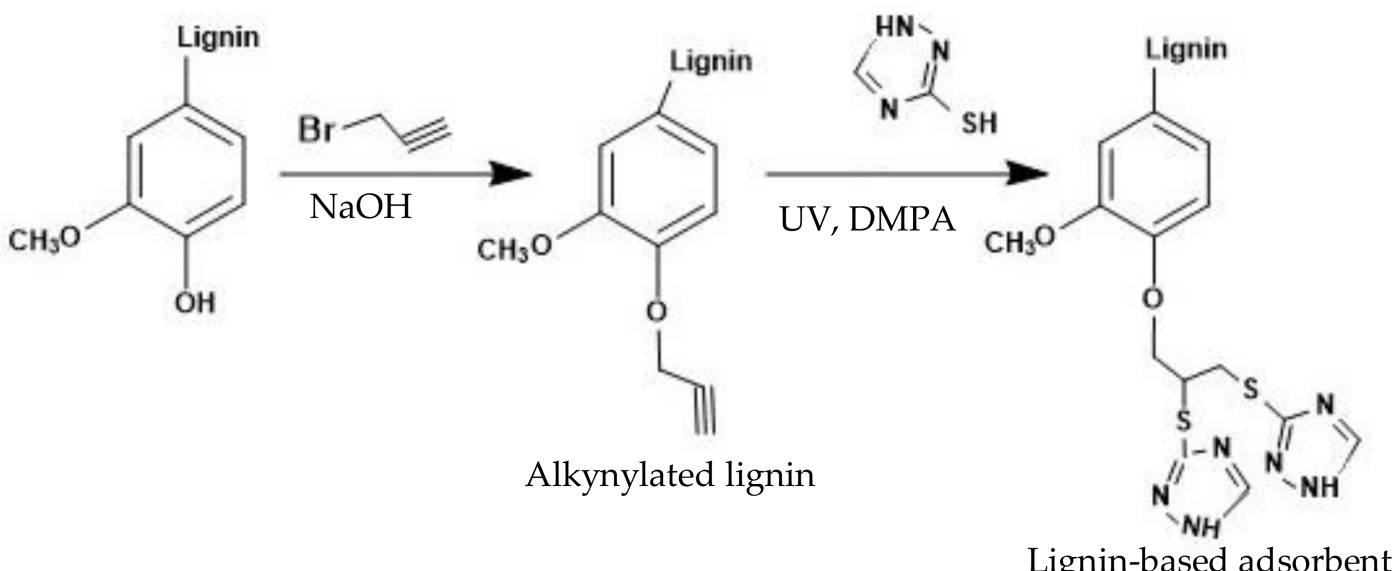

Figure 4. Schematic reaction mechanism of thiol-yne alkynylation lignin [69].

In all cases stated above on modified lignin, maximum adsorbed mass is correlated to the charged groups and molecular weight of lignin, which in turn enhanced the solubility of modified lignin. But even insoluble lignin seems to be an efficient adsorbent. In one study, a two-step process to synthesize porous lignin has been developed [70]. Mannich reaction to graft polyethylenimine (PEI) onto alkali lignin matrix at $90{ }^{\circ} \mathrm{C}$ for $5 \mathrm{~h}$ was first implemented to introduce amine groups to lignin. Then, carbon disulfide was used for completing modification, while introducing dithiocarbamate groups to lignin. The final product possessed $8.5 \mathrm{mmol} / \mathrm{g}$ of nitrogen and $2.8 \mathrm{mmol} / \mathrm{g}$ of dithiocarbamate groups. The higher surface area of this adsorbent $\left(22.3 \mathrm{~m}^{2} / \mathrm{g}\right)$ compared to lignin $\left(1.8 \mathrm{~m}^{2} / \mathrm{g}\right)$ confirmed the porous structure of the functionalized lignin matrix. The final product exhibited excellent adsorption performance toward lead ions with $90 \%$ removal from the solution $(120 \mathrm{mg} / \mathrm{g})$. However, the two stages of the Mannich and esterification reaction may be too complex to be implemented in industry. Yang and coworkers formed a lignin-based interconnected foam in an oil/water interface by in-situ polymerization containing lignin $(1 \mathrm{wt} . \%)$ and melamine formaldehyde $(25 \mathrm{wt} . \%)$ in a water/toluene mixture at $60{ }^{\circ} \mathrm{C}$ for $4 \mathrm{~h}$ [73]. The product was employed to remove $\mathrm{Cu}^{2+}$ and $\mathrm{Cd}^{2+}$ from wastewater. The highest adsorbed capacities of $73.2 \mathrm{mg} / \mathrm{g}$ and $142.3 \mathrm{mg} / \mathrm{g}$ were reported for $\mathrm{Cu}^{2+}$ and $\mathrm{Cd}^{2+}$, respectively.

\subsection{Adsorbent for Dyes}

Table 4 demonstrates that lignocellulosic material can be a good candidate to remove dyes from aqueous media. Unmodified wheat straw lignin with a molecular weight of $3510 \mathrm{~g} / \mathrm{mol}$ and carboxylate content of $3.8 \mathrm{mmol} / \mathrm{g}$ was applied for adsorbing Brilliant Red dye [50]. Thermodynamic parameters confirmed a spontaneous endothermic adsorption process. The driving force for adsorption 
stems from electrostatic interaction between the oppositely charged groups of lignin and dye. The highest adsorption capacity was $10.13 \mathrm{mg} / \mathrm{g}$ at $20^{\circ} \mathrm{C}$.

Table 4. Lignin as an adsorbent for dye removal.

\begin{tabular}{cccc}
\hline Material & Adsorbent & Adsorption Capacity & Reference \\
\hline Brilliant Red HE-3B dye & Wheat straw lignin & $10.17 \mathrm{mg} / \mathrm{g}$ & {$[50]$} \\
Methylene Blue dye & Esterified Lignin & $31.23 \mathrm{mg} / \mathrm{g}$ & {$[74]$} \\
Brilliant Red 2BE dye & Etherified lignin-Fe $^{3+}$ complex & $73.6 \mathrm{mg} / \mathrm{g}$ & {$[75]$} \\
Anthraquinonic dye & Chitosan-alkali lignin complex $^{3+}$ complex & $73.52 \mathrm{mg} / \mathrm{g}$ & {$[76]$} \\
Procion Blue dye & Carboxymethylated lignin-Al ${ }^{2+}$ complex & $55.16 \mathrm{mg} / \mathrm{g}$ & {$[77]$} \\
Methylene Blue & Carboxymethylated lignin-Mn ${ }^{2+}$ & {$[50]$} \\
\hline
\end{tabular}

The counterions attached to lignin were proposed to influence its adsorption efficiency. In one work, carboxymethylated lignin was produced under basic conditions via reacting with monochloroacetic acid [75]. The product was treated with $\mathrm{FeCl}_{3} \cdot 6 \mathrm{H}_{2} \mathrm{O}$ solution for $24 \mathrm{~h}$ to ensure that $\mathrm{Fe}^{3+}$ was coupled to the lignin backbone. The final product with a molecular weight of $1890 \mathrm{~g} / \mathrm{mol}$ was shown to be a potential adsorbent for Brilliant Red dye. The high adsorbed amount of $73.6 \mathrm{mg} / \mathrm{g}$ indicated an electrostatic attraction between carboxymethyl Fe-based lignin and an anionic dye. In another study, $\mathrm{Al}^{3+}$ and $\mathrm{Mn}^{2+}$ based carboxymethylated lignins were produced and the coagulation of Procion blue dye with these lignins was studied [77]. Al-lignin and Fe-lignin complexes showed similar adsorption capacity [75,77]; while the Mn-based lignin complex yielded a lower adsorption capacity. This difference may be attributed to the ion charge capacities of the metals.

$\mathrm{Li}$ and coworkers used larch-based and poplar-based lignins to form esterified lignin via reacting lignin with maleic anhydride in acetone at $60{ }^{\circ} \mathrm{C}$ [78]. The esterified lignins, along with $\mathrm{Fe}_{3} \mathrm{O}_{4}$ nanoparticles, were dissolved in tetrahydrofuran. After investigating the adsorption capacity of modified lignins for Methylene Blue dye, it was observed that larch-based adsorbent with the molecular weight of $3200 \mathrm{~g} / \mathrm{mol}$ exhibited an adsorption capacity of $31.23 \mathrm{mg} / \mathrm{g}$. Monolayer surface coverage of lignin with dyes was claimed to occur via van der Waals interaction between the benzene ring of the dye and the esterified lignin. Results obtained from this insoluble lignin suggests that adsorbent's particle diameter and surface area play significant roles on its adsorption capacity. Also, the incorporation of $\mathrm{Fe}_{3} \mathrm{O}_{4}$ may hinder the commercialization step to produce such adsorbent.

\subsection{Adsorbent for Other Applications}

Lignin appears to be an excellent adsorbent in chemical processes, which is tabulated in Table 5. As a 2,4,6-Trinitrotoluene (TNT) adsorbent for military wastes, the chlorinated/aminated lignin was prepared by reacting lignin with 1,2-dichloroethane monomer and aluminum chloride [79]. The chlorinated lignin was aminated via reacting with $\mathrm{N}, \mathrm{N}$-dimethylformamide and ethylenediamine monomers. Adsorption of TNT on lignin reached $55.7 \mathrm{mg} / \mathrm{g}$, mostly through hydrogen bonding.

In the past, lignin had also been used as an adsorbent to recover gold from the mining industry. In one report, kraft lignin in an acidic $\mathrm{HCl}$ solution was used to uptake gold at $40{ }^{\circ} \mathrm{C}$ [80], where $100 \%$ coagulation of gold and lignin was achieved due to the reduction of $\mathrm{Au}(\mathrm{III})$ ions by acidic $\mathrm{Cl}^{-}$ions in a redox reaction. Thermodynamics of adsorption documented that the gold flakes were formed in an endothermic $(\Delta \mathrm{H}>0)$ entropy-driven process $(\Delta \mathrm{S}>0)$. This high removal of gold was attributed to attachment of $\mathrm{AuCl}_{4}^{-}$complex to the positively charged surface of adsorbent through electrostatic interactions. However, high dissolution of lignin at elevated temperatures was a barrier for this process, and the use of other water insoluble lignin in developing adsorbents needs to be evaluated in the future. 
Table 5. Lignin as an adsorbent in other chemicals.

\begin{tabular}{cccc}
\hline Material & Adsorbent & Adsorption Capacity & Reference \\
\hline TNT & Chlorinated aminated lignin & $55.7 \mathrm{mg} / \mathrm{g}$ & {$[79]$} \\
2-nitrophenol & Hydrolysis lignin & $1.8 \mathrm{mg} / \mathrm{g}$ & {$[81]$} \\
Bisphenol & Black liquor isolated lignin & $237.07 \mathrm{mg} / \mathrm{g}$ & {$[82]$} \\
Metamitron, metribuzin pesticide & rot-wood lignin & $53 \%$ & $62 \%$ \\
Dazomet/tiram pesticide & Indulin kraft lignin & $38-40 \%$ & {$[83]$} \\
Hexazinone pesticide & Indulin kraft lignin & $47 \%$ & {$[84]$} \\
$\mathrm{Au}(\mathrm{II})$ & Crosslinked lignophenol & $\geq 30 \%$ & {$[85]$} \\
$\mathrm{Au}(\mathrm{III})$ & HCl mediated kraft lignin & $100 \%$ & {$[86]$} \\
$\mathrm{Au}(\mathrm{III})$ & Aminated lignin & $100 \%$ & {$[77]$} \\
$\mathrm{Pd}(\mathrm{II})$ & & $80 \%$ & {$[86]$} \\
\hline
\end{tabular}

\section{Dispersants}

Dispersants are widely used for suspending colloidal particles in cosmetics, paints, pharmaceuticals, drilling mud, cement, and ceramic applications [87]. Many synthetic polymers have been used as dispersants [88-90]. However, their toxic nature and/or non-biodegradability limits their use in industry [89]. The semi-natural or natural polymers have been proposed to be utilized as dispersants [91]. Lignin has been modified and used as a dispersant for different applications, as listed in Table 6.

Figure 5 shows the mechanism of dispersants in stabilizing particles in suspensions. In Figure 5a, the adsorption of a dispersant, e.g., lignin, increases the surface charge density of particles, which enhances repulsion force development between particles and stabilizes them in suspensions. In Figure 5b, the adsorption of a dispersant, e.g., lignin, improves the hydrophilicity of particles and thus facilitates the interaction of water molecules and hydrated particles, thus reducing the hydrophobic/hydrophobic interaction developed between particles to prevent their agglomeration [92,93].

a

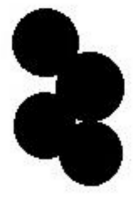

b
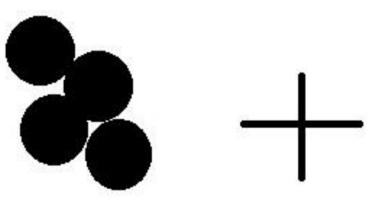
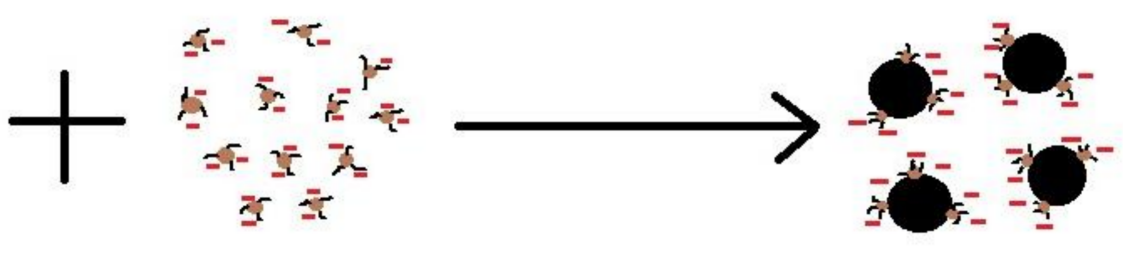

$=$

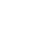


Table 6. Proposed lignin-based dispersants for various fields.

\begin{tabular}{|c|c|c|c|c|c|}
\hline Lignin Type & Application & Charge Density (meq/g) & Molecular Weight (g/mol) & Modification & References \\
\hline Hardwood kraft lignin & Cement admixture & -1.60 & 53,360 & Sulfomethylation & [94] \\
\hline Softwood kraft lignin & $\begin{array}{l}\text { Stellar clay, cement, calcium } \\
\text { carbonate and titanium dioxide }\end{array}$ & $\mathrm{N} / \mathrm{A}$ & $\mathrm{N} / \mathrm{A}$ & Ozone oxidation & [95] \\
\hline Softwood kraft lignin & Kaolin suspension & -2.2 & 14,825 & Oxidation & [96] \\
\hline Lignin N/A & Carbon nanotubes nanofluids & N/A & $\mathrm{N} / \mathrm{A}$ & As is & [97] \\
\hline Straw alkali lignin & Dispersant for graphite suspension & $\mathrm{N} / \mathrm{A}$ & $\mathrm{N} / \mathrm{A}$ & Carboxymethylation & [98] \\
\hline Softwood kraft lignin & Dispersant for cement admixture & -3.8 & 18,299 & Oxidation and sulfomethylation & [44] \\
\hline Hardwood lignin & Kaolin suspension & $(-) 1.2-3.62$ & $26,700-83,543$ & Oxidation & [99] \\
\hline Hardwood kraft lignin & Kaolin suspension & 1.80 & 29,960 & Carboxymethylation & [94] \\
\hline Kraft lignin & Dimethomorph suspension & $\mathrm{N} / \mathrm{A}$ & $18,061-29,201$ & $\begin{array}{l}\text { Grafting poly(ethylene glycol) functionalized with } \\
\text { epichlorohydrin using } \mathrm{BF}_{3}-\mathrm{Et}_{2} \mathrm{O}\end{array}$ & [100] \\
\hline Wheat straw kraft lignin & Cement admixture & $\mathrm{N} / \mathrm{A}$ & 25,700 & Sulfonation & [101] \\
\hline Wheat straw alkali lignin & Cement admixture & N/A & 9688 & Hydroxymethylation and sulfonation & [102] \\
\hline Pinewood alkali lignin & Dye suspension & $\mathrm{N} / \mathrm{A}$ & 11,020 & Hydroxypropylation and sulfonation & [103] \\
\hline Spruce alkali lignin & Multiwalled carbon nanotubes & $\mathrm{N} / \mathrm{A}$ & 14,000 & As is & [104] \\
\hline Softwood kraft lignin & Multiwalled carbon nanotubes & $\mathrm{N} / \mathrm{A}$ & $\begin{array}{c}6500-7000 \text { and } \\
34,000-36,000\end{array}$ & Fractionization & [105] \\
\hline Wheat straw alkali lignin & $\mathrm{TiO}_{2}$ slurry & $\mathrm{N} / \mathrm{A}$ & $17,400-35,700$ & Sulfomethylation, horseradish peroxide utilization & [106] \\
\hline Esparto grass lignin & Cement admixture & $\mathrm{N} / \mathrm{A}$ & 10,000 & Sulfonation & [107] \\
\hline Acid precipitated lignin & Cement admixture & N/A & N/A & Sulfonation & [108] \\
\hline
\end{tabular}




\subsection{Dispersant for Dyes}

Dispersive dyes have very low solubility in aqueous solutions. Adding dispersants is beneficial for preventing agglomeration of dye particles and for stabilizing dye dispersion [103]. Dispersants prevent the agglomeration of particles by introducing steric hindrance and electrostatic force among particles $[109,110]$. Commercial dispersants are mainly naphthalene-sulfonated formaldehyde and acid-phenol-formaldehyde condensates. Sulfonated lignin has been used as a dispersant for dye dispersion.

Qin and coworkers produced a dispersant for dye suspension through hydroxypropyl sulfonation of pinewood alkali lignin (HSL) (Table 6) under the conditions of 10/3.5 (w/w) lignin/sodium 3-chloro-2-hydroxy-propanesulfonate at $90{ }^{\circ} \mathrm{C}$ for $2 \mathrm{~h}$, which was followed by crosslinking reaction with epichlorohydrin for $1 \mathrm{~h} \mathrm{[103].} \mathrm{The} \mathrm{produced} \mathrm{products} \mathrm{had} \mathrm{a} \mathrm{molecular} \mathrm{weight} \mathrm{of} 11,020 \mathrm{~g} / \mathrm{mol}$ and contained $2.10 \mathrm{mmol} / \mathrm{g}$ of sulfonate group. The produced polymers and commercial sodium naphthalene sulfonic acid formaldehyde (SNF) dispersant showed similar results in dispersing dye particles.

It was observed that temperature affected the dispersion process in that a more dispersed dye solution was observed at a lower temperature of $25^{\circ} \mathrm{C}$ [103]. The molecular weight of the sulfonated product also impacted the dispersion of dyes. The increase in the molecular weight of lignin-based dispersants from $8750 \mathrm{~g} / \mathrm{mol}$ to $11,020 \mathrm{~g} / \mathrm{mol}$ reduced the particle size of azo dye by $40 \%$. On the other hand, increasing the molecular weight from 11,020 to $14,830 \mathrm{~g} / \mathrm{mol}$ increased the particle size of an azo dye by $36 \%$ [103]. Therefore, the molecular weight of the dispersant should be tailored for achieving an acceptable efficiency.

\subsection{Dispersant for Cement}

Dispersants are used in the construction industry to boost the fluidity of concrete and decrease the water content of cement pastes [111,112]. Generally, sulfonated products are used as dispersants for cement admixtures. This is because sulfonate anions have more hydrophilic affinity than carboxylate anions [110]. However, common dispersants used in cement admixtures, such as sulfonated melamin-formaldehyde and sulfonated naphthalene-formaldehyde, have the disadvantages of enhanced concrete shrinkage, meager dispersibility, and pollution [113,114].

In the past, hardwood kraft lignin was sulfomethylated (Table 6) under the conditions of sodium hydroxymethylsulfonate/lignin ratios of $0.3-1.2 \mathrm{~mol} / \mathrm{mol}$ in the temperature range between 80 and $140{ }^{\circ} \mathrm{C}$ and different periods of time $(1-4 \mathrm{~h})$. This process improved the anionic charge density and molecular weight of lignin to $-1.60 \mathrm{meq} / \mathrm{g}$ and $53,360 \mathrm{~g} / \mathrm{mol}$, respectively. The application of this lignin (1.2 wt. \%) improved the cement fluidity by 50\% [94]. In another work, the oxidation (with 10-30 wt. \% nitric acid, $60-100{ }^{\circ} \mathrm{C}$ and $0.5-4 \mathrm{~h}$ ) and sulfomethylation $\left(\mathrm{CH}_{2} \mathrm{O} /\right.$ lignin of 0.4-1.2 $\mathrm{mol} / \mathrm{mol}$ and $\mathrm{Na}_{2} \mathrm{~S}_{2} \mathrm{O}_{5} /$ lignin of $0.3-0.7 \mathrm{~mol} / \mathrm{mol}, 60-100{ }^{\circ} \mathrm{C}$ and $0.5-4 \mathrm{~h}$ ) of softwood kraft lignin generated a sulfomethylated lignin with the charge density and molecular weight of $-3.8 \mathrm{meq} / \mathrm{g}$ and $18,299 \mathrm{~g} / \mathrm{mol}$, respectively. The $0.5 \mathrm{wt}$. \% dosage of this product increased the fluidity of cement from $65 \mathrm{~mm}$ to $200 \mathrm{~mm}$ [44].

In another study, kraft lignin from wheat straw was sulfonated (Table 6) by sodium sulfite in water in the temperature range between 45 and $55{ }^{\circ} \mathrm{C}$. The product was hydroxymethylated via reacting with formaldehyde aqueous solution of $37 \%$ concentration at $98^{\circ} \mathrm{C}$ for $3 \mathrm{~h}$, which generated a sulfonated lignin with sulfonate group contents in a range between 1.5 to $3.7 \mathrm{mmol} / \mathrm{g}$ and the molecular weight of $30,000 \mathrm{~g} / \mathrm{mol}$. The results depicted that the use of this product yielded a fluidity of $290 \mathrm{~mm}$, which was higher than that of a commercial naphthalene dispersant $(250 \mathrm{~mm})$ for a cement paste [101]. In another study, esparto grass lignin (Table 6) was sulfonated with sodium sulfite and formaldehyde, which generated sulfonated lignin with a molecular weight of 10,000 g/mol, and the sulfonate degree of $0.8 \mathrm{mmol} / \mathrm{g}$. The use of sulfonated lignin in cement at the dosage of $0.4-0.6 \%$ showed a remarkable decrease in water requirement of cement (7-12\%) [107]. In another work, a more complicated scenario was followed for producing sulfonated lignin [102]. At first, wheat straw 
alkali lignin was oxidized under the conditions of 10/2/0.1 (w/w/w) alkali lignin $/ \mathrm{H}_{2} \mathrm{O}_{2} / \mathrm{FeSO}_{4}$ at $55-95{ }^{\circ} \mathrm{C}$ for $1 \mathrm{~h}$. The product was then hydroxymethylated with $37 \% \mathrm{HCHO}$ at $75^{\circ} \mathrm{C}$ for $2 \mathrm{~h}$. Finally, the sulfonation reaction was conducted with $\mathrm{Na}_{2} \mathrm{SO}_{3} /$ lignin ratio of $1-2 / 4(w / w)$ at $75-95{ }^{\circ} \mathrm{C}$ for $3 \mathrm{~h}$. As reported, the produced sulfonated lignin could improve the dispersion of the cement admixture by $3 \%$ more than the commercial lignosulfonate [102]. The charge density and molecular weight seemed to impact the performance of sulfonated lignin in dispersing cement.

Ozone was also used as an oxidizing agent for producing lignin-based dispersants. In one study, alkali lignin was ozonated under the conditions of $50-55^{\circ} \mathrm{C}$ for $2 \mathrm{~h}$ (Table 6) and used as a dispersant for clay, titanium dioxide, cement and calcium carbonate suspensions (the suspension concentrations were $41,35,68.5$, and $50 \mathrm{wt}$. \%, respectively, at the dispersant concentrations of 0.126 , $0.25,1$, and $0.25 \mathrm{wt}$. $\%$, respectively). It was observed that the produced modified lignin could decrease the viscosity of clay, titanium dioxide, cement, and calcium carbonate suspensions up to $77,98,86$, and $90 \%$, respectively [95].

Table 7 lists the applications of lignosulfonates in industries as dispersants. The use of lignosulfonate as a dispersant for cement had been studied recently due to its acceptable performance and cost-effectiveness [115-117]. In some studies, lignosulfonate was modified to improve its dispersant performance in cement. In one study, calcium lignosulfonate was modified through oxidation (using hydrogen peroxide/lignosulfonate ratio of $0.12(w / w)$ at $80^{\circ} \mathrm{C}$ for $1.5 \mathrm{~h}$ ), hydroxymethylation (using formaldehyde/lignosulfonate ratio of $0.35(w / w)$ for $2 \mathrm{~h}$ at $80^{\circ} \mathrm{C}$ ) and sulfomethylation (using sodium sulfite/lignosulfonate mass ratio of 0.2 and formaldehyde/lignosulfonate mass ratio of 0.2 for $2 \mathrm{~h}$ at $90{ }^{\circ} \mathrm{C}$ ). The performance of the product was evaluated as a dispersant for cement admixture. The adsorption of the oxidized, hydroxymethylated, and sulfomethylated lignosulfonates onto the cement surface was increased 7.5, 6.9, and 1.2 times with respect to that of the unmodified lignosulfonate, respectively. Although the adsorption of hydroxymethylated lignosulfonate was remarkable, its dispersion performance was rather poor compared to the oxidized and sulfomethylated lignosulfonates. The better dispersion performance of oxidized and sulfomethylated lignosulfonates was attributed to their higher negative charge densities [118]. In another work, sodium lignosulfonate underwent two consecutive reactions of oxidation (using 30\% polyacrylic acid and $0.5 \%$ iron (II) sulfate for $2 \mathrm{~h}$ at $80^{\circ} \mathrm{C}$ ) and sulfomethylation (using $20 \%$ of formaldehyde and $30 \%$ of sodium sulfite for $3 \mathrm{~h}$ at $95^{\circ} \mathrm{C}$ ). These modifications led to an increase in both molecular weight (up to 10 times) and sulfonate content (up to two times) of the sodium lignosulfonate, which made the polymer 15\% more efficient than the unmodified sodium lignosulfonate in enhancing the fluidity of a cement paste [115].

The counter ions attached to lignosulfonate may impact its efficiency as a dispersant. Among calcium, magnesium, sodium, and potassium lignosulfonates; calcium lignosulfonate was reported to reduce the cement viscosity, while magnesium lignosulfonate could hamper the cement admixture's viscosity [117]. In addition, calcium lignosulfonate demonstrated the highest (11.1\%) and sodium lignosulfonate showed the lowest (6.5\%) capacity in reducing the water use of cement paste [117]. 
Table 7. Lignosulfonates as dispersants in various applications.

\begin{tabular}{|c|c|c|c|c|c|}
\hline Lignosulfonate Type & Application & Charge Density (meq/g) & Molecular Weight (g/mol) & Modification & Reference \\
\hline NA & Electroceramic suspensions & $-0.061 \pm 0.002 \mathrm{C} / \mathrm{m}^{2}$ & 37,000 & No modification & [119] \\
\hline NA & Gypsum paste & NA & $9000-62,000$ & $\begin{array}{l}\text { Hydroxymethylation, sulfonation, phenolation, } \\
\text { sulfomethylation, arylsulfonation }\end{array}$ & [120] \\
\hline NA & Coal-water slurry & NA & $2000-17,000$ & No modification & [59] \\
\hline Sodium lignosulfonate & Coal-water slurry & NA & less than 5000 to more than 50,000 & No modification & [121] \\
\hline Calcium lignosulfonate & Titanium dioxide suspension & NA & less than 1000 -more than 30,000 & No modification & [122] \\
\hline Calcium lignosulfonate & Cement admixture & NA & NA & $\begin{array}{l}\text { Oxidation, sulfomethylation, } \\
\text { hydroxymethylation }\end{array}$ & [118] \\
\hline NA & Dimethomorph suspension & NA & Less than $1000-$ more than 30,000 & No modification & [123] \\
\hline Hardwood lignosulfonate & Cement admixture & NA & NA & No modification & [120] \\
\hline NA & Dimethomorph suspension & NA & $4800-160,000$ & No modification & [123] \\
\hline Sodium lignosulfonate & Ceramic suspension & NA & 13,000 & No modification & [124] \\
\hline Sodium lignosulfonate & Concrete admixture & NA & 2378 and 23,650 & Oxidation, sulfomethylation & [115] \\
\hline NA & Dye suspension & NA & $9010-17,307$ & No modification & [125] \\
\hline NA & Dimethomorph suspension & NA & $9600-35,500$ & Oxidation, sulfonation & [126] \\
\hline NA & Carbendazim suspension & NA & $1900-13,120$ & Sulfobutylation & [127] \\
\hline NA & Coal-water slurry & NA & $13,100-251,000$ & Alkyl chain coupling polymerization & [128] \\
\hline $\begin{array}{l}\text { Calcium, magnesium, sodium, } \\
\text { potassium lignosulfonate }\end{array}$ & Cement admixture & NA & NA & No modification & [117] \\
\hline
\end{tabular}

NA: not available. 


\subsection{Dispersant for Mineral Particles}

Kaolin suspensions are used as raw materials for paper, ceramic, healthcare formulations, and pharmaceutical applications [129-131]. In these applications, the fluidity of a kaolin paste without settling is important to produce the products with appropriate properties [125,132]. By using dispersants, they adsorb on particle's surfaces and change the overall surface charge density of the suspensions by inducing electrostatic or steric repulsion between particles. Various synthetic polymers, such as sodium tripolyphosphate and sodium polyphosphate, are used for dispersing kaolin suspensions, but their toxicity, price, and non-biodegradability are the main barriers for their implementation in industry [89,133].

Lignin based dispersants were also used for kaolin dispersion. He and coworkers oxidized softwood kraft lignin (Table 6) using hydrogen peroxide under varied reaction times (1-3 h) and temperatures $\left(60-100{ }^{\circ} \mathrm{C}\right)$, which generated oxidized lignin derivatives with the charge density of $-2.2 \mathrm{meq} / \mathrm{g}$ and molecular weight of 14,825 g/mol (Figure 6) [96]. Several lignin derivatives can be generated in this reaction, but the exact product of this reaction was not identified [96]. The anionic product improved the dispersion of kaolin suspensions by $18 \%$. In another study, hardwood lignin (Table 6) was oxidized by using nitric acid (4-12 wt. \% nitric acid/lignin at $100{ }^{\circ} \mathrm{C}$ for $1 \mathrm{~h}$ ), and the product with the charge density of $-3.6 \mathrm{meq} / \mathrm{g}$ and molecular weight of $30,243 \mathrm{~g} / \mathrm{mol}$ showed the best performance in dispersing kaolin suspensions. Dispersion studies in this work suggested that both molecular weight and charge density had great impacts on the stability of kaolin particles [97].<smiles>[R]c1cc(C(O)CC)ccc1O</smiles>

R: $\mathrm{H}$ or $\mathrm{OCH}_{3}$

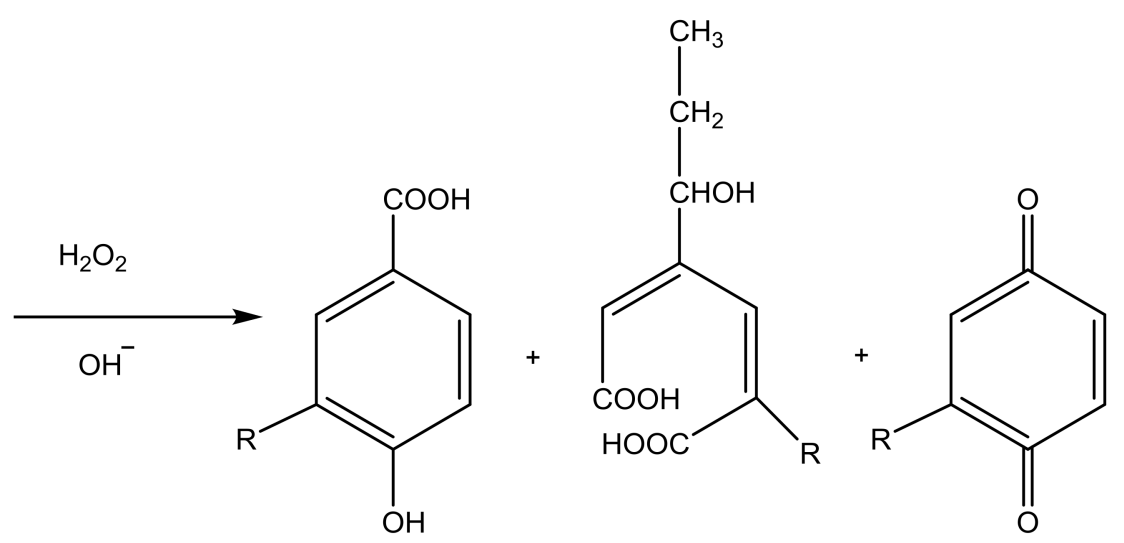

Figure 6. Oxidation of softwood kraft lignin [96].

Various lignin-based chemicals have been used to other suspensions, such as titanium dioxide slurry and graphite suspensions [98,100,106]. Graphite is extensively used in different industries, such as ceramics, and conductive coating, due to its corrosion resistance, superior electric, thermal conductivity, and chemical stability. Since graphite is a non-polar mineral with strong hydrophobicity, it is difficult to disperse it in polar solvents, such as water. However, in most of the applications, graphite particles should be dispersed in aqueous suspensions [134]. To address this challenge, wheat straw alkali lignin was carboxymethylated using monochloroacetic acid under the conditions of monochloroacetic acid/lignin ratio of $6 / 10(w / w)$ at $70{ }^{\circ} \mathrm{C}$ for $90 \mathrm{~min}$. As reported, carboxymethylated lignin with the dosage of $1 \mathrm{wt}$ \% enhanced the suspension stability of graphite by around $4 \%$ [98].

Titanium dioxide $\left(\mathrm{TiO}_{2}\right)$ is a material broadly used in plastics, inks, papermaking, paints, ceramics, and fibers, where its dispersion is critical [135,136]. However, titanium dioxide particles tend to agglomerate due to their large surface area. In order to address this problem, sulfomethylated wheat straw alkali lignin was modified by the horseradish peroxidase (HRP) under the conditions of ratio of $3 / 0.41(w / w)$ lignin/formaldehyde at $95{ }^{\circ} \mathrm{C}$ for $1 \mathrm{~h}$. After the reaction, the sulfonate and carboxylate 
groups, and the molecular weight of lignin were increased by $55 \%, 75 \%$, and $470 \%$, respectively. The dispersion performance of the produced polymer in titanium dioxide suspension showed a reduction of $84 \%$ in $\mathrm{TiO}_{2}$ particle size [106].

\subsection{Dispersant for Coal-Water Slurry}

Coal-water slurry is one of the alternative energy sources, which is cost-effective and easy to handle. Since this slurry contains a high coal content to meet the energy requirement, the water content of the slurry is of great importance. To reduce the water requirement, dispersants are used for diminishing the interaction among the particles in the slurry $[133,137]$. Lignosulfonate by itself may not be an effective dispersant for the coal-water slurry. As an inexpensive product, several studies were carried out to improve the efficiency of lignosulfonate as a dispersant for the slurry [138]. In one study, the molecular weight of lignosulfonate has been increased through the reaction of alkyl chain (conducted under alkaline condition using 1,6-dibromohexane in various mass ratios of lignosulfonate/1,6-dibromohexane of 1/0.08,1/0.12,1/0.16, 1/0.24, and 1/0.30, and potassium iodide for $8 \mathrm{~h}$ at $70{ }^{\circ} \mathrm{C}$ ) and the products were used as dispersants for the coal-water slurry. It was disclosed that the lignosulfonate's molecular weight was increased from 42,800 g/mol to 125,000 g/mol. All produced lignosulfonates worked better than the unmodified lignosulfonate and naphthalene sulfonate formaldehyde in reducing the coal-water slurry's viscosity. This result was attributed to the higher molecular weights of the produced polymers, which may affect their adsorption affinity on the coal particles [128].

Ultrafiltration was used as a method to generate lignosulfonates with different molecular weights to refine them as dispersants for coal-water slurry [121,138]. The results showed that sulfonate group content of lignosulfonates with the lowest $(2000 \mathrm{~g} / \mathrm{mol})$ and highest $(17,000 \mathrm{~g} / \mathrm{mol})$ molecular weights were 1.36 and $1 \mathrm{mmol} / \mathrm{g}$, respectively. Also, the carboxylate group content was determined to be 1.72 and $1.04 \mathrm{mmol} / \mathrm{g}$ for the highest and the lowest molecular weight lignosulfonate, respectively [138]. Overall, the molecular weight range of $10,000-30,000 \mathrm{~g} / \mathrm{mol}$ was reported to be optimum for lignosulfonate to act as a dispersant for coal-water slurry [138].

\subsection{Dispersant for Carbon Nanotubes Suspensions}

Aqueous carbon nanotube (CNT) nanofluids have widely been studied for the preparation of nanocomposite materials with enhanced properties $[139,140]$, such as large surface area, small size, remarkable electrical conductivity, and high mechanical strength [141-143]. However, they have poor solubility in water due to their tendency to agglomerate through van der Waals forces [144], which hampers CNTs' utilization and application as dispersants. Although chemical and physical treatments have been suggested to address this problem $[145,146]$, the disadvantage of chemical modification of CNTs is the disconnection of $\pi$-networks within CNTs, causing a decline in their electrical and mechanical properties [146,147]. Adding surfactants or polymers help cover CNTs by noncovalent interactions $[148,149]$. By adsorbing polar polymers on CNTs, intermolecular hydrogen bonding functionalized CNTs would enable CNT dispersion [150,151]. The most commonly used surfactants for this purpose are sodium dodecylsulfate, sodium dodecylbenzene sulfonate, octyl phenol ethoxylate, and hemadecyltrimethylammonium bromide [152-157].

Kraft lignin has been shown to have an efficient dispersion performance for CNTs. In one study, lignin (Table 6) was used without any modification as a dispersant for CNT, and its performance was compared with that of sodium dodecylbenzene sulfonate (SDBS). The results revealed that lignin ( 2 wt. \%) could reduce the suspension's viscosity by 70\% (comparing to SDBS) without increasing the thermal conductivity of the suspension. Thus, it was suggested that lignin acted better than SDBS in dispersing the carbon nanotubes suspended in water at 0.55 vol. \% [97].

Rochez and coworkers used spruce alkali lignin (Table 6) with the molecular weight of $14,000 \mathrm{~g} / \mathrm{mol}$ to disperse multiwalled carbon nanotubes (MWCNT). By adding $10 \mathrm{~g} / \mathrm{L}$ of lignin to $1 \mathrm{wt}$. $\%$ of MWCNT suspension, the transmission electron microscopy analysis showed that the nanotubes 
were distributed in the polymer matrix without morphological degradation or aggregation [104]. In another study, spruce wood alkali lignin, with the molecular weight of $14,000 \mathrm{~g} / \mathrm{mol}$ (Table 6) was used to disperse multiwalled carbon nanotubes (MWCNT). Lignin was added to MWCNT with a lignin/MWCNT ratio of 1/6 (w/w). The lignin-MWCNT dispersion stability was monitored for several months at ambient conditions through which the lignin efficiency to disperse multiwalled carbon nanotubes was proved [104].

\subsection{Dispersants for Other Suspensions}

Dimethomorph, named (E,Z)-4-[3-(4-chlorophenyl)-3-(3,4-dimethoxyphenyl) acryloyl] morpholine, is a fungicide, which acts as a pesticide by protecting vegetables and plants from downy mildews, late blights, crown, and root rots [123]. The utilization of this pesticide requires its mixing with water. System stability and dispersion are critically important since the ingredients need to spread evenly on the plant surface after spraying [123]. Lin and coworkers dispersed a dimethomorph suspension by a synthesized pine kraft lignin-based polyoxyethylene ether (KL-PEG) [100]. KL-PEG production was carried out via reacting kraft lignin with poly(ethylene glycol) in a weight ratio of 100/0.8. The ethoxyethane-trifluoroborane then proceeded at $55^{\circ} \mathrm{C}$ for $2 \mathrm{~h}$ [100]. The products had a molecular weight ranging from 18,061 to 29,201 g/mol (Table 6). Among three different samples with similar molecular weights, the highest dimethomorph dispersion of $99.2 \%$ was observed using lignin modified with ethoxyethane-trifluoroborane/poly (ethylene glycol) in a molar ratio of 1/1, while dimethomorph dispersion was 93.1\% using commercial lignosulfonate [100].

Lignosulfonate has also been studied as a dispersant for the dimethomorph suspension. In one study, the dispersion performance of lab-made and commercial lignosulfonates with different molecular weights and sulfonate groups were evaluated in an aqueous dimethomorph suspension (Table 7) [124]. As reported, both the lab-made and commercial lignosulfonates could act as dispersants for dimethomorph suspensions with similar results in reducing dimethomorph's particle size. It was revealed that the lab-made lignosulfonate having a molecular mass of $16,000 \mathrm{~g} / \mathrm{mol}$ contributed to the system stability through steric repulsive forces; while the commercial lignosulfonate with higher sulfonate groups provided the system stability with the electrostatic repulsive forces [124].

The effects of lignosulfonate's molecular weight and sulfonate group content were analyzed in two other studies on the dimethomorph suspension stability (Table 7). It was revealed that the higher the polymer's molecular weight, the greater its adsorption and thus the greater the electrostatic repulsion force between the particles, leading to the stability of dimethomorph. It was also reported that a lignosulfonate with a molecular weight higher than $30,000 \mathrm{~g} / \mathrm{mol}$ was inefficient in dispersing dimethomorph due to its longer branched structure that might bridge the particles [123,126]. Lignosulfonates with similar molecular weights, but various sulfonation degrees, were also evaluated for their dispersion performance in the dimethomorph granule suspension, and the results revealed that an increase in the sulfonation degree from 1.58 to $1.81 \mathrm{mmol} / \mathrm{g}$ increased the suspending ratio by $10 \%$ [123].

In addition, the performance of sulfonated lignin with various cations of sodium, magnesium, and iron as a dispersant was evaluated and it was determined that an increase in the valence of a cation led to a slight enhancement (i.e., 4\%) in the dispersion performance [123]. However, in order to increase the efficiency of lignin-based dispersants, lignin needs to undergo various chemical modifications to increase its charge density and solubility. Discovering the reactions with high efficiency and environmentally friendly features is a challenge.

Matsushita and Yasuda produced several types of sulfonated lignin by hydroxymethylating, sulfonating, phenolating, sulfomethylating and arylsulfonating of the phenolated lignin to use as dispersants in gypsum pastes [120]. It was also claimed that the increase in molecular weight (to around $15,000 \mathrm{~g} / \mathrm{mol}$ ) and sulfur content (to $11.4 \%$ ) enhanced the dispersibility of the gypsum paste by $70 \%$ compared to the commercial lignosulfonate [120]. 
In another work, lignosulfonate was sulfobutylated (using varied proportions of 1,4-butane sulfonate and 1,6-dibromohexane for $7 \mathrm{~h}$ at $70{ }^{\circ} \mathrm{C}$ ) and used as a dispersant for the antifungal agent carbendazim suspensions. It was found that the modified lignosulfonates having the molecular weights of 11,850 and $13,120 \mathrm{~g} / \mathrm{mol}$ with sulfonate group contents of 2.66 and $2.18 \mathrm{mmol} / \mathrm{g}$, respectively, improved the dispersion properties of the suspension and that these samples could act as better dispersants than a commercial lignosulfonate [127].

Yang and coworkers (2008) investigated the dispersion performance of calcium lignosulfonate with different molecular weights in the range of less than $1000 \mathrm{~g} / \mathrm{mol}$ to more than 30,000 g/mol in a titanium dioxide suspension (Table 7) and observed that an increase in the molecular weight from $927 \mathrm{~g} / \mathrm{mol}$ to $21,646 \mathrm{~g} / \mathrm{mol}$ led to an increase in the adsorption of lignosulfonate on titanium oxide particles [125]. Lignosulfonate with the molecular weight of $7621 \mathrm{~g} / \mathrm{mol}$ had the highest sulfonate group content of $10.28 \mathrm{wt}$. \% and showed the best dispersion performance in the dosage below $4 \mathrm{mg} / \mathrm{L}$. System stabilization, in this case, has been pronounced to be due to the electrostatic forces between the titanium dioxide particles. Meanwhile, by increasing the modified lignosulfonate concentration, the sample with a higher molecular weight $(21,646 \mathrm{~g} / \mathrm{mol})$ demonstrated a better dispersion via promoting steric hindrance.

\section{Conclusions}

Although promising results were reported for the modification and application of lignin as flocculants, adsorbents, and dispersants, the modification procedures seemed to be industrially unattractive, as they mainly applied solvent-based systems. Also, more analyses were carried out for assessing the performance of lignin-based flocculants, adsorbents, and dispersants in simulated samples than industrially produced samples. The application of these products in industrially produced samples must be examined for further development of lignin-based processes for valorizing lignin. Although the results on the importance of molecular weight and charge density of lignin-based flocculants are available in literature, the contribution of lignin in the flocculation systems should be investigated in detail. The use of lignin as a flocculant for dyes has been examined more than for other wastewater effluents. However, the volume of municipal and industrial wastes produced annually make the expansion for the potential use of lignin-based flocculants in these effluents appealing. The use of unmodified lignin as an adsorbent for dyes and heavy metals appears promising, and its simplicity in use may be attractive to industry. The uses of unmodified and modified lignin and lignosulfonate as dispersants were more practiced in the past and the reports showed a similar performance (or better) for lignin-based dispersants than for synthetic ones. Different values were reported as optimum values for molecular weight and charge density of lignin-based dispersants for altered systems. These results suggest that the properties performance relationships for lignin-based dispersants are case dependent.

Acknowledgments: The authors would like to thank NSERC Canada, Canada Research Chairs, and Northern Ontario Heritage Fund Corporation programs for supporting this research.

Conflicts of Interest: The authors declare no conflict of interest.

\section{References}

1. Schwarzenbach, R.P.; Escher, B.I.; Fenner, K.; Hofstetter, T.B.; Johnson, C.A.; Von Gunten, U.; Wehrli, B. The challenge of micropollutants in aquatic systems. Science 2006, 313, 1072-1077. [CrossRef] [PubMed]

2. Luong, N.D.; Binh, N.T.T.; Park, I.-K.; Lee, S.H.; Kim, D.S.; Lee, Y.S.; Lee, Y.K.; Kim, B.W.; Kim, K.H.; Yoon, H.K. Chemical and rheological characteristics of thermally stable kraft lignin polycondensates analyzed by dielectric properties. BioResources 2013, 8, 4518-4532.

3. Marinović, V.; Ristić, M.; Dostanić, M. Dynamic adsorption of trinitrotoluene on granular activated carbon. J. Hazard. Mater. 2005, 117, 121-128. [CrossRef] [PubMed] 
4. Wei, Y.; Cheng, F.; Zheng, H. Synthesis and flocculating properties of cationic starch derivatives. Carbohydr. Polym. 2008, 74, 673-679. [CrossRef]

5. Akin, D.; Benner, R. Degradation of polysaccharides and lignin by ruminal bacteria and fungi. Appl. Environ. Microb. 1988, 54, 1117-1125.

6. Mathers, R.T. How well can renewable resources mimic commodity monomers and polymers? J. Polym. Sci. A Polym. Chem. 2012, 50,1-15. [CrossRef]

7. Belgacem, M.; Gandini, A. Monomers, Polymers and Composites from Renewable Resources, 1st ed.; Elsiver: Amsterdam, The Netherland, 2008.

8. Boerjan, W.; Ralph, J.; Baucher, M. Lignin biosynthesis. Annu. Rev. Plant Biol. 2003, 54, 519-546. [CrossRef] [PubMed]

9. Dorrestijn, E.; Laarhoven, L.J.; Arends, I.W.; Mulder, P. The occurrence and reactivity of phenoxyl linkages in lignin and low rank coal. J. Anal. Appl. Pyrol. 2000, 54, 153-192. [CrossRef]

10. Mousavioun, P.; Doherty, W.O. Chemical and thermal properties of fractionated bagasse soda lignin. Ind. Crops Prod. 2010, 31, 52-58. [CrossRef]

11. Kong, F.; Parhiala, K.; Wang, S.; Fatehi, P. Preparation of cationic softwood kraft lignin and its application in dye removal. Eur. Polym. J. 2015, 67, 335-345. [CrossRef]

12. Caballero-Calero, O.; Díaz-Chao, P.; Abad, B.; Manzano, C.; Ynsa, M.; Romero, J.; Rojo, M.M.; Martín-González, M. Improvement of Bismuth Telluride electrodeposited films by the addition of Sodium Lignosulfonate. Electrochim. Acta 2014, 123, 117-126. [CrossRef]

13. Chung, Y.-L.; Olsson, J.V.; Li, R.J.; Frank, C.W.; Waymouth, R.M.; Billington, S.L.; Sattely, E.S. A renewable lignin-lactide copolymer and application in biobased composites. ACS Sustain. Chem. Eng. 2013, 1, 1231-1238. [CrossRef]

14. Crestini, C.; Crucianelli, M.; Orlandi, M.; Saladino, R. Oxidative strategies in lignin chemistry: A new environmental friendly approach for the functionalisation of lignin and lignocellulosic fibers. Catal. Today 2010, 156, 8-22. [CrossRef]

15. Lü, Q.-F.; Luo, J.J.; Lin, T.T.; Zhang, Y.Z. Novel Lignin-Poly (N-methylaniline) Composite Sorbent for Silver Ion Removal and Recovery. ACS Sustain. Chem. Eng. 2013, 2, 465-471. [CrossRef]

16. Feng, Q.; Chen, F.; Wu, H. Preparation and characterization of a temperature-sensitive lignin-based hydrogel. BioResources 2011, 6, 4942-4952. [CrossRef]

17. Thakur, V.K.; Thakur, M.K. Recent advances in green hydrogels from lignin: A review. Int. J. Biol. Macromol. 2015, 72, 834-847. [CrossRef] [PubMed]

18. Li, R.; Yang, D.; Guo, W.; Qiu, X. The adsorption and dispersing mechanisms of sodium lignosulfonate on $\mathrm{Al} 2 \mathrm{O} 3$ particles in aqueous solution. Holzforschung 2013, 67, 387-394. [CrossRef]

19. Oveissi, F.; Sitter, T.; Fatehi, P. PDADMAC as a flocculant for lignosulfonate of NSSC pulping process. Biotechnol. Prog. 2016, 32, 686-691. [CrossRef] [PubMed]

20. Telysheva, G.; Dizhbite, T.; Paegle, E.; Shapatin, A.; Demidov, I. Surface-active properties of hydrophobized derivatives of lignosulfonates: Effect of structure of organosilicon modifier. J. Appl. Polym. Sci. 2001, 82, 1013-1020. [CrossRef]

21. Klapiszewski, Ł.; Szalaty, T.J.; Szatkowski, T.; Jesionowski, T. Lignosulfonate as a byproduct of wood pulp production: A potential precursor for the preparation of functional hybrid materials. Ann. Chem. 2016, 71, 47. [CrossRef]

22. Aro, T.; Fatehi, P. Production and application of lignosulfonates and sulfonated lignin. ChemSusChem 2017, 10, 1861-1877. [CrossRef] [PubMed]

23. Ji, X.; Dong, Y.; Yuan, B.; Li, B.; Guo, M. Influence of glutaraldehyde on the performance of a lignosulfonate/chitosan-based medium density fiberboard adhesive. J. Appl. Polym. Sci. 2018, 135, 45870. [CrossRef]

24. Fatehi, P.; Gao, W.; Sun, Y.; Dashtban, M. Acidification of prehydrolysis liquor and spent liquor of neutral sulfite semichemical pulping process. Bioresour. Technol. 2016, 218, 518-525. [CrossRef] [PubMed]

25. Carrott, P.; Carrott, M.R. Lignin-From natural adsorbent to activated carbon: A review. Bioresour. Technol. 2007, 98, 2301-2312. [CrossRef]

26. Singh, R.P.; Nayak, B.R.; Biswal, D.R.; Tripathy, T.; Banik, K. Biobased polymeric flocculants for industrial effluent treatment. Mater. Res. Innov. 2003, 7, 331-340. [CrossRef] 
27. Li, W.W.; Zhou, W.Z.; Zhang, Y.Z.; Wang, J.; Zhu, X.B. Flocculation behavior and mechanism of an exopolysaccharide from the deep-sea psychrophilic bacterium Pseudoalteromonas sp. SM9913. Bioresour. Technol. 2008, 99, 6893-6899. [CrossRef] [PubMed]

28. Lu, Q.; Yan, B.; Xie, L.; Huang, J.; Liu, Y.; Zeng, H. A two-step flocculation process on oil sands tailings treatment using oppositely charged polymer flocculants. Sci. Total Environ. 2016, 565, 369-375. [CrossRef] [PubMed]

29. Gumfekar, S.P.; Rooney, T.R.; Hutchinson, R.A.; Soares, J.B. Dewatering Oil Sands Tailings with Degradable Polymer Flocculants. ACS Appl. Mater. Interfaces 2017, 9, 36290-36300. [CrossRef] [PubMed]

30. Shih, I.L.; Van, Y.T.; Yeh, L.C.; Lin, H.G.; Chang, Y.N. Production of a biopolymer flocculant from Bacillus licheniformis and its flocculation properties. Bioresour. Technol. 2001, 78, 267-272. [CrossRef]

31. You, L.; Lu, F.; Li, D.; Qiao, Z.; Yin, Y. Preparation and flocculation properties of cationic starch/chitosan crosslinking-copolymer. J. Hazard. Mater. 2009, 172, 38-45. [CrossRef] [PubMed]

32. Semerjian, L.; Ayoub, G.M. High-pH-magnesium coagulation-flocculation in wastewater treatment. Adv. Environ. Res. 2003, 7, 389-403. [CrossRef]

33. Sillanpaa, M.; Matilainen, A. NOM removal by coagulation. In Natural Organic Matter in Water: Characterization and Treatment Methods, 1st ed.; Butterworth-Heinemann Elsevier Ltd.: Oxford, UK, 2014.

34. Li, R.; Gao, B.; Sun, S.; Yue, Q.; Li, M.; Yang, X.; Jia, R. Amine-Cross-Linked Lignin-Based Polymer: Modification, Characterization, and Flocculating Performance in Humic Acid Coagulation. ACS Sustain. Chem. Eng. 2015, 3, 3253-3261. [CrossRef]

35. Fang, G.Z.; He, W.H.; Song, Z.Q. Synthesis and performance of quaternary ammonium salt of lignin as cationic flocculant. Chem. Ind. For. Prod. 2003, 23, 37-41.

36. Zhang, Q.; Wang, D.; Bei, Y.; Ren, S.; Fang, G. Flocculation performance of trimethyl quaternary ammonium salt of lignin-sodium alginate polyampholyte. BioResources 2013, 8, 3544-3555. [CrossRef]

37. Couch, R.L.; Price, J.T.; Fatehi, P. Production of Flocculant from Thermomechanical Pulping Lignin via Nitric Acid Treatment. ACS Sustain. 2016, 4, 1954-1962. [CrossRef]

38. Fang, R.; Cheng, X.; Xu, X. Synthesis of lignin-base cationic flocculant and its application in removing anionic azo-dyes from simulated wastewater. Bioresour. Technol. 2010, 101, 7323-7329. [CrossRef] [PubMed]

39. Rong, H.; Gao, B.; Zhao, Y.; Sun, S.; Yang, Z.; Wang, Y.; Li, Q. Advanced lignin-acrylamide water treatment agent by pulp and paper industrial sludge: Synthesis, properties and application. J. Environ. Sci. 2013, 25, 2367-2377. [CrossRef]

40. Rong, H.; Gao, B.; Dong, M.; Zhao, Y.; Sun, S.; Yue, Q.; Li, Q. Characterization of size, strength and structure of aluminum-polymer dual-coagulant flocs under different $\mathrm{pH}$ and hydraulic conditions. J. Hazard. Mater. 2013, 252, 330-337. [CrossRef] [PubMed]

41. He, W.; Zhang, Y.; Fatehi, P. Sulfomethylated kraft lignin as a flocculant for cationic dye. Colloids Surf. A Physicochem. Eng. Asp. 2016, 503, 19-27. [CrossRef]

42. Liu, H.; Yang, X.; Liu, X.; Yao, H.; Li, Y. Study on preparation and application in flocculants of modified lignin. Mod. Appl. Sci. 2011, 5, 205. [CrossRef]

43. Haroon, M.H. Flocculation and Dewatering of Kaolinite Suspensions and Oil Sands Mature Fine Tailings Using Dual Polymers. Master's Thesis, University of Alberta, Edmonton, AB, Canada, 2014.

44. He, K.; Lou, T.; Wang, X.; Zhao, W. Preparation of lignosulfonate-acrylamide-chitosan ternary graft copolymer and its flocculation performance. Int. J. Biol. Macromol. 2015, 81, 1053-1058. [CrossRef] [PubMed]

45. Vishtal, A.G.; Kraslawski, A. Challenges in industrial applications of technical lignins. BioResources 2011, 6, 3547-3568.

46. Mishra, A.; Bajpai, M. The flocculation performance of Tamarindus mucilage in relation to removal of vat and direct dyes. Bioresour. Technol. 2006, 97, 1055-1059. [CrossRef] [PubMed]

47. Nigam, P.; Armour, G.; Banat, I.M.; Singh, D.; Marchant, R. Physical removal of textile dyes from effluents and solid-state fermentation of dye-adsorbed agricultural residues. Bioresour. Technol. 2000, 72, 219-226. [CrossRef]

48. Mohan, D.; Pittman, C.U., Jr.; Steele, P.H. Single, binary and multi-component adsorption of copper and cadmium from aqueous solutions on Kraft lignin-a biosorbent. J. Colloid Interface Sci. 2006, 297, 489-504. [CrossRef] [PubMed] 
49. Chakrabarti, S.; Banerjee, S.; Chaudhuri, B.; Bhattacharjee, S.; Dutta, B.K. Application of biodegradable natural polymers for flocculated sedimentation of clay slurry. Bioresour. Technol. 2008, 99, 3313-3317. [CrossRef] [PubMed]

50. Suteu, D.; Malutan, T.; Bilba, D. Removal of reactive dye Brilliant Red HE-3B from aqueous solutions by industrial lignin: Equilibrium and kinetics modeling. Desalination 2010, 255, 84-90. [CrossRef]

51. Altaf, A.; Noor, S.; Sharif, Q.M.; Najeebullah, M. Different techniques recently used for the treatment of textile dyeing effluents: A review. J. Chem. Soc. Pak. 2010, 32, 115-116.

52. Qu, Y.Y.; Yang, Q.; Zhou, J.T.; Gou, M.; Xing, L.L.; Ma, F. Combined MBR with photocatalysis/ozonation for bromoamine acid removal. Appl. Biochem. Biotechnol. 2009, 159, 664-672. [CrossRef] [PubMed]

53. Maximova, N.; Österberg, M.; Koljonen, K.; Stenius, P. Lignin adsorption on cellulose fibre surfaces: Effect on surface chemistry, surface morphology and paper strength. Cellulose 2001, 8, 113-125. [CrossRef]

54. Imel, A.E.; Naskar, A.K.; Dadmun, M.D. Understanding the impact of poly (ethylene oxide) on the assembly of lignin in solution toward improved carbon fiber production. ACS Appl. Mater. Interfaces 2016, 8, 3200-3207. [CrossRef] [PubMed]

55. Oveissi, F.; Fatehi, P. Characterization of four different lignins as a first step toward the identification of suitable end-use applications. J. Appl. Polym. Sci. 2015, 132. [CrossRef]

56. Alriols, M.G.; Tejado, A.; Blanco, M.A.; Mondragon, I.; Labidi, J. Agricultural palm oil tree residues as raw material for cellulose, lignin and hemicelluloses production by ethylene glycol pulping process. Chem. Eng. J. 2009, 148, 106-114. [CrossRef]

57. Sun, R.; Tomkinson, J. Comparative study of lignins isolated by alkali and ultrasound-assisted alkali extractions from wheat straw. Ultrason. Sonochem. 2002, 9, 85-93. [CrossRef]

58. Zhou, Q.; Chen, Z.H. Chemical properties of the fractionated compounds from wheat straw alkali lignin. Trans. China Pulp Pap. 1998, 13, 1-4.

59. Zhou, M.; Qiu, X.; Yang, D.; Lou, H.; Ouyang, X. High-performance dispersant of coal-water slurry synthesized from wheat straw alkali lignin. Fuel Sci. Technol. 2007, 88, 375-382. [CrossRef]

60. Okamura, H.; Aoyama, I. Interactive toxic effect and distribution of heavy metals in phytoplankton. Environ. Toxicol. 1994, 9, 7-15. [CrossRef]

61. Erbring, H.; Peter, H. Zur Kenntnis des Lignins. Kolloid-Zeitschrift 1941, 96, 47-71. [CrossRef]

62. Guo, X.; Zhang, S.; Shan, X.-Q. Adsorption of metal ions on lignin. J. Hazard. Mater. 2008, 151, $134-142$. [CrossRef] [PubMed]

63. Wu, Y.; Zhang, S.; Guo, X.; Huang, H. Adsorption of chromium (III) on lignin. Bioresour. Technol. 2008, 99, 7709-7715. [CrossRef] [PubMed]

64. Jin, W.; Zhang, Z.; Wu, G.; Tolba, R.; Chen, A. Integrated lignin-mediated adsorption-release process and electrochemical reduction for the removal of trace Cr (VI). RSC Adv. 2014, 4, 27843-27849. [CrossRef]

65. Albadarin, A.B.; Ala'a, H.; Al-Laqtah, N.A.; Walker, G.M.; Allen, S.J.; Ahmad, M.N. Biosorption of toxic chromium from aqueous phase by lignin: Mechanism, effect of other metal ions and salts. Chem. Eng. J. 2011, 169, 20-30. [CrossRef]

66. Šćiban, M.B.; Klašnja, M.T.; Antov, M.G. Study of the biosorption of different heavy metal ions onto Kraft lignin. Ecol. Eng. 2011, 37, 2092-2095. [CrossRef]

67. Merdy, P.; Guillon, E.; Aplincourt, M. Iron and manganese surface complex formation with extracted lignin. Part 1: Adsorption isotherm experiments and EPR spectroscopy analysis. New J. Chim. 2002, 26, 1638-1645. [CrossRef]

68. Todorciuc, T.; Bulgariu, L.; Popa, V.I. Adsorption of Cu (II) from aqueous solution on wheat straw lignin: Equilibrium and kinetic studies. Cellul. Chem. Technol. 2015, 49, 439-447.

69. Jin, C.; Zhang, X.; Xin, J.; Liu, G.; Wu, G.; Kong, Z.; Zhang, J. Clickable synthesis of 1,2,4-triazole modified lignin-based adsorbent for the selective removal of Cd (II). ACS Sustain. Chem. Eng. 2017, 5, 4086-4093. [CrossRef]

70. Li, Z.; Xiao, D.; Ge, Y.; Koehler, S. Surface-functionalized porous lignin for fast and efficient lead removal from aqueous solution. ACS Appl. Mater. Interfaces 2015, 7, 15000-15009. [CrossRef] [PubMed]

71. Luo, X.; Liu, C.; Yuan, J.; Zhu, X.; Liu, S. Interfacial Solid-Phase Chemical Modification with Mannich Reaction and Fe (III) Chelation for Designing Lignin-Based Spherical Nanoparticle Adsorbents for Highly Efficient Removal of Low Concentration Phosphate from Water. ACS Sustain. Chem. Eng. 2017, 5, 6539-6547. [CrossRef] 
72. Parajuli, D.; Inoue, K.; Ohto, K.; Oshima, T.; Murota, A.; Funaoka, M.; Makino, K. Adsorption of heavy metals on crosslinked lignocatechol: A modified lignin gel. React. Funct. Polym. 2005, 62, 129-139. [CrossRef]

73. Yang, Y.; Wei, Z.; Wang, C.; Tong, Z. Lignin-based Pickering HIPEs for macroporous foams and their enhanced adsorption of copper (II) ions. J. Chem. Soc. Chem. Commun. 2013, 49, 7144-7146. [CrossRef] [PubMed]

74. Li, Y.; Wu, M.; Wang, B.; Wu, Y.; Ma, M.; Zhang, X. Synthesis of magnetic lignin-based hollow microspheres: A highly adsorptive and reusable adsorbent derived from renewable resources. ACS Sustain. Chem. Eng. 2016, 4, 5523-5532. [CrossRef]

75. Da Silva, L.G.; Ruggiero, R.; Gontijo, P.D.M.; Pinto, R.B.; Royer, B.; Lima, E.C.; Fernandes, T.H.; Calvete, T. Adsorption of Brilliant Red 2BE dye from water solutions by a chemically modified sugarcane bagasse lignin. Chem. Eng. J. 2011, 168, 620-628. [CrossRef]

76. Nair, V.; Panigrahy, A.; Vinu, R. Development of novel chitosan-lignin composites for adsorption of dyes and metal ions from wastewater. Chem. Eng. J. 2014, 254, 491-502. [CrossRef]

77. Adebayo, M.A.; Prola, L.D.; Lima, E.C.; Puchana-Rosero, M.; Cataluna, R.; Saucier, C.; Umpierres, C.S.; Vaghetti, J.C.; da Silva, L.G.; Ruggiero, R. Adsorption of Procion Blue MX-R dye from aqueous solutions by lignin chemically modified with aluminium and manganese. J. Hazard. Mater. 2014, 268, 43-50. [CrossRef] [PubMed]

78. Li, S.; Ogunkoya, D.; Fang, T.; Willoughby, J.; Rojas, O.J. Carboxymethylated lignins with low surface tension toward low viscosity and highly stable emulsions of crude bitumen and refined oils. J. Colloid Interface Sci. 2016, 482, 27-38. [CrossRef] [PubMed]

79. Zhang, J.; Lin, X.; Luo, X.; Zhang, C.; Zhu, H. A modified lignin adsorbent for the removal of 2,4,6trinitrotoluene. Chem. Eng. J. 2011, 168, 1055-1063. [CrossRef]

80. Adhikari, B.B.; Gurung, M.; Alam, S.; Tolnai, B.; Inoue, K. Kraft mill lignin-A potential source of bio-adsorbents for gold recovery from acidic chloride solution. Chem. Eng. J. 2013, 231, 190-197. [CrossRef]

81. Allen, S.J.; Koumanova, B.; Kircheva, Z.; Nenkova, S. Adsorption of 2-nitrophenol by technical hydrolysis lignin: Kinetics, mass transfer, and equilibrium studies. Ind. Eng. Chem. Res. 2005, 44, 2281-2287. [CrossRef]

82. Han, W.; Luo, L.; Zhang, S. Adsorption of bisphenol A on lignin: Effects of solution chemistry. Int. J. Environ. Sci. Technol. 2012, 9, 543-548. [CrossRef]

83. Ludvík, J.; Zuman, P. Adsorption of 1,2,4-triazine pesticides metamitron and metribuzin on lignin. Microchem. J. 2000, 64, 15-20. [CrossRef]

84. Rupp, E.B.; Zuman, P.; Sestakova, I.; Horak, V. Polarographic determination of some pesticides. Application to a study of their adsorption on lignin. J. Agric. Food Chem. 1992, 40, 2016-2021. [CrossRef]

85. Privman, M.; Rupp, E.B.; Zuman, P. Hexazinone: Polarographic reduction and adsorption on lignin. J. Agric. Food Chem. 1994, 42, 2946-2952. [CrossRef]

86. Parajuli, D.; Kawakita, H.; Inoue, K.; Funaoka, M. Recovery of gold (III), palladium (II), and platinum (IV) by aminated lignin derivatives. Ind. Eng. Chem. Res. 2006, 45, 6405-6412. [CrossRef]

87. Sharma, B.R.; Dhuldhoya, N.C.; Merchant, U.C. Flocculants-an ecofriendly approach. J. Polym. Environ. 2006, 14, 195-202. [CrossRef]

88. Brumbach, M.; Carty, W.M. Dispersant demand curves: Effect of PAA on the viscosity of several clays. Ceram. Eng. Sci. Proc. 2003, 24, 183.

89. Papo, A.; Piani, L.; Ricceri, R. Sodium tripolyphosphate and polyphosphate as dispersing agents for kaolin suspensions: Rheological characterization. Colloids Surf. A Physicochem. Eng. Asp. 2002, 201, 219-230. [CrossRef]

90. Piani, L.; Papo, A. Sodium tripolyphosphate and polyphosphate as dispersing agents for alumina suspensions: Rheological characterization. J. Eng. 2013, 2013. [CrossRef]

91. Qin, Y.; Yang, D.; Gu, F.; Li, X.; Xiong, W.; Zhu, J.Y. Biorefinery lignosulfonates as a dispersant for coal water slurry. Sustain. Chem. Process. 2016, 4, 5. [CrossRef]

92. Konduri, M.K.; Fatehi, P. Adsorption and dispersion performance of oxidized sulfomethylated kraft lignin in coal water slurry. Fuel Procss. Technol. 2018, in press.

93. He, W.; Fatehi, P. Preparation of sulfomethylated softwood kraft lignin as a dispersant for cement admixture. RSC Adv. 2015, 58, 47031-47039. [CrossRef]

94. Konduri, M.K.; Fatehi, P. Production of water-soluble hardwood Kraft Lignin via Sulfomethylation using formaldehyde and sodium sulfite. ACS Sustain. Chem. Eng. 2015, 3, 1172-1182. [CrossRef] 
95. Detroit, J. Lignin Dispersing Agent. U.S. Patent No. 3726, 17 January 2012.

96. He, W.; Gao, W.; Fatehi, P. Oxidation of Kraft Lignin with Hydrogen Peroxide and its Application as a Dispersant for Kaolin Suspensions. ACS Sustain. Chem. Eng. 2017, 5, 10597-10605. [CrossRef]

97. Estelle, P.; Halelfadl, S.; Mare, T. Lignin as dispersant for water-based carbon nanotubes nanofluids: Impact on viscosity and thermal conductivity. Int. J. Heat Mass Transf. 2014, 57, 8-12. [CrossRef]

98. Gan, L.; Zhou, M.; Yang, D.; Qiu, X. Preparation and evaluation of carboxymethylated lignin as dispersant for aqueous graphite suspension using Turbiscan Lab analyzer. J. Dispers. Sci. Technol. 2013, 34, 644-650. [CrossRef]

99. Konduri, M.K.; Fatehi, P. Designing anionic lignin based dispersant for kaolin suspensions. Colloids Surf. A Physicochem. Eng. Asp. 2018, 538, 639-650. [CrossRef]

100. Lin, X.; Zhou, M.; Wang, S.; Lou, H.; Yang, D.; Qiu, X. Synthesis, structure, and dispersion property of a novel lignin-based polyoxyethylene ether from kraft lignin and poly (ethylene glycol). ACS Sustain. Chem. Eng. 2014, 2, 1902-1909. [CrossRef]

101. Lou, H.; Zhu, J.; Lan, T.Q.; Lai, H.; Qiu, X. pH-Induced lignin surface modification to reduce nonspecific cellulase binding and enhance enzymatic saccharification of lignocelluloses. ChemSusChem 2013, 6, 919-927. [CrossRef] [PubMed]

102. Ouyang, X.; Ke, L.; Qiu, X.; Guo, Y.; Pang, Y. Sulfonation of alkali lignin and its potential use in dispersant for cement. J. Dispers. Sci. Technol. 2009, 30,1-6. [CrossRef]

103. Qin, Y.; Yang, D.; Qiu, X. Hydroxypropyl sulfonated lignin as dye dispersant: Effect of average molecular weight. ACS Sustain. Chem. Eng. 2015, 3, 3239-3244. [CrossRef]

104. Rochez, O.; Zorzini, G.; Amadou, J.; Claes, M.; Richel, A. Dispersion of multiwalled carbon nanotubes in water by lignin. J. Mater. Sci. 2013, 48, 4962-4964. [CrossRef]

105. Teng, N.Y.; Dallmeyer, I.; Kadla, J.F. Effect of softwood kraft lignin fractionation on the dispersion of multiwalled carbon nanotubes. Ind. Eng. Chem. 2013, 52, 6311-6317. [CrossRef]

106. Zhou, H.; Chang, Y.; Wu, X.; Yang, D.; Qiu, X. Horseradish peroxidase modification of sulfomethylated wheat straw alkali lignin to improve its dispersion performance. ACS Sustain. Chem. Eng. 2015, 3, 518-523. [CrossRef]

107. Kamoun, A.; Jelidi, A.; Chaabouni, M. Evaluation of the performance of sulfonated esparto grass lignin as a plasticizer-water reducer for cement. Cem. Concr. Res. 2003, 33, 995-1003. [CrossRef]

108. Qiu, X.-Q.; Wang, B.; Lou, H.-M.; Yang, D.-J. Graft Sulfonation and Water Reducing-Performance Strengthening Effect of Acid Precipitation Lignin. J. South China Univ. Technol. 2007, 4, 3.

109. Kano, K.; Minamizono, H.; Kitae, T.; Negi, S. Self-Aggregation of Cationic Porphyrins in Water. Can $\pi-\pi$ Stacking Interaction Overcome Electrostatic Repulsive Force? J. Phys. Chem. Biophys. 1997, 101, 6118-6124. [CrossRef]

110. Deng, Y.; Zhang, W.; Wu, Y.; Yu, H.; Qiu, X. Effect of molecular weight on the adsorption characteristics of lignosulfonates. J. Phys. Chem. 2011, 115, 14866-14873. [CrossRef] [PubMed]

111. Heikal, M.; Morsy, M.S.; Aiad, I. Effect of polycarboxylate superplasticizer on hydration characteristics of cement pastes containing silica fume. Ceram. Silik. 2006, 50, 5-14.

112. Lim, G.G.; Hong, S.S.; Kim, D.S.; Lee, B.J.; Rho, J.S. Slump loss control of cement paste by adding polycarboxylic type slump-releasing dispersant. Cem. Concr. Res. 1999, 29, 223-229. [CrossRef]

113. Ran, Q.; Miao, C.; Liu, J.; Wu, S.; Shen, J. Performance and mechanism of a multi-functional superplasticizer for concrete. Mater. Trans. 2006, 47, 1599-1604. [CrossRef]

114. Ran, Q.; Somasundaran, P.; Miao, C.; Liu, J.; Wu, S.; Shen, J. Adsorption mechanism of comb polymer dispersants at the cement/water interface. J. Dispers. Sci. Technol. 2010, 31, 790-798. [CrossRef]

115. Yu, G.; Li, B.; Wang, H.; Liu, C.; Mu, X. Preparation of concrete superplasticizer by oxidation-sulfomethylation of sodium lignosulfonate. BioResources 2013, 8, 1055-1063. [CrossRef]

116. Mudiastuti, S.; Suryokusumo, S.; Syahbirin, G.; Yumairoh, Y. Prospect of sodium lignosulfonate derived from hardwood black liquor as ingredient in mortar. Int. Soc. Southeast Asian Agric. Sci. J. 2011, 17, 184-193.

117. Arel, H.Ş.; Aydin, E. Effects of Ca-, Mg-, K-, and Na-lignosulfonates on the behavior of fresh concrete. Constr. Build. Mater. 2017, 157, 1084-1091. [CrossRef]

118. Pang, Y.X.; Qiu, X.Q.; Yang, D.J.; Lou, H.M. Influence of oxidation, hydroxymethylation and sulfomethylation on the physicochemical properties of calcium lignosulfonate. Colloids Surf. Physicochem. Eng. Asp. 2008, 312, 154-159. [CrossRef] 
119. Ratinac, K.R.; Standard, O.C.; Bryant, P.J. Lignosulfonate adsorption on and stabilization of lead zirconate titanate in aqueous suspension. J. Colloid Interface Sci. 2004, 273, 442-454. [CrossRef] [PubMed]

120. Matsushita, Y.; Yasuda, S. Preparation and evaluation of lignosulfonates as a dispersant for gypsum paste from acid hydrolysis lignin. Bioresour. Technol. 2005, 96, 465-470. [CrossRef] [PubMed]

121. Yang, D.; Qiu, X.; Zhou, M.; Lou, H. Properties of sodium lignosulfonate as dispersant of coal water slurry. Energy Convers. Manag. 2007, 48, 2433-2438. [CrossRef]

122. Yang, D.; Qiu, X.; Pang, Y.; Zhou, M. Physicochemical properties of calcium lignosulfonate with different molecular weights as dispersants in aqueous suspension. J. Dispers. Sci. Technol. 2008, 29, 1296-1303. [CrossRef]

123. Li, Z.; Pang, Y.; Lou, H.; Qiu, X. Influence of lignosulfonates on the properties of dimethomorph water-dispersible granules. BioResources 2009, 4, 589-601.

124. Li, Z.; Pang, Y.; Ge, Y.; Qiu, X. Evaluation of steric repulsive force in the aqueous dispersion system of dimethomorph powder with lignosulfonates via X-ray photoelectron spectroscopy. J. Phys. Chem. C 2013, 115, 24865-24870. [CrossRef]

125. Yang, D.; Li, H.; Qin, Y.; Zhong, R.; Bai, M.; Qiu, X. Structure and properties of sodium lignosulfonate with different molecular weight used as dye dispersant. J. Dispers. Sci. Technol. 2015, 36, 532-539. [CrossRef]

126. Pang, Y.; Gao, W.; Lou, H.; Zhou, M.; Qiu, X. Influence of modified lignosulfonate GCL4-1 with different molecular weight on the stability of dimethomorph water based suspension. Colloids Surf. Physicochem. Eng. Asp. 2014, 441, 664-668. [CrossRef]

127. Qiu, X.; Zeng, W.; Yu, W.; Xue, Y.; Pang, Y.; Li, X.; Li, Y. Alkyl chain cross-linked sulfobutylated lignosulfonate: A highly efficient dispersant for carbendazim suspension concentrate. ACS Sustain. Chem. Eng. 2015, 3, 1551-1557. [CrossRef]

128. Hong, N.; Li, Y.; Zeng, W.; Zhang, M.; Peng, X.; Qiu, X. Ultrahigh molecular weight, lignosulfonate-based polymers: Preparation, self-assembly behaviors and dispersion property in coal-water slurry. RSC Adv. 2015, 5, 21588-21595. [CrossRef]

129. Baird, J.C.; Walz, J.Y. The effects of added nanoparticles on aqueous kaolinite suspensions: II. Rheological effects. Colloid Interface Sci. 2007, 306, 411-420. [CrossRef] [PubMed]

130. Zhang, L.; Lu, Q.; Xu, Z.; Liu, Q.; Zeng, H. Effect of polycarboxylate ether comb-type polymer on viscosity and interfacial properties of kaolinite clay suspensions. J. Colloid Interface Sci. 2012, 378, 222-231. [CrossRef] [PubMed]

131. Schott, H. Controlled flocculation of coarse suspensions by colloidally dispersed solids I: Interaction of bismuth subnitrate with bentonite. J. Pharm. Sci. 1976, 65, 855-861. [CrossRef] [PubMed]

132. Marco, P.; Llorens, J. Adsorption of some linear copolymers onto kaolin particles in concentrated suspensions. Colloids Surf. A Physicochem. Eng. Asp. 2005, 270, 291-295. [CrossRef]

133. Pawlik, M. Polymeric dispersants for coal-water slurries. Colloids Surf. Physicochem. Eng. Asp. 2005, 266, 82-90. [CrossRef]

134. Yoo, M.; Frank, C.W.; Mori, S.; Yamaguchi, S. Effect of poly (vinylidene fluoride) binder crystallinity and graphite structure on the mechanical strength of the composite anode in a lithium ion battery. Polymer 2003, 44, 4197-4204. [CrossRef]

135. Boisvert, J.P.; Persello, J.; Castaing, J.C.; Cabane, B. Dispersion of alumina-coated $\mathrm{TiO}_{2}$ particles by adsorption of sodium polyacrylate. Colloids Surf. A. Physicochem. Eng. Asp. 2001, 178, 187-198. [CrossRef]

136. Farrokhpay, S.; Morris, G.E.; Fornasiero, D.; Self, P. Effects of chemical functional groups on the polymer adsorption behavior onto titania pigment particles. J. Colloid Interface Sci. 2004, 274, 33-40. [CrossRef] [PubMed]

137. Konduri, M.K. New Generation of Dispersants by Grafting Lignin or Xylan. Ph.D. Thesis, Lakehead University, Thunder Bay, ON, Canada, 2017.

138. Zhou, M.; Qiu, X.; Yang, D.; Lou, H. Properties of Different Molecular Weight Sodium Lignosulfonate Fractions as Dispersant of Coal-Water Slurry. J. Dispers. Sci. Technol. 2004, 27, 851-856. [CrossRef]

139. Iijima, S. Helical microtubules of graphitic carbon. Nature 1991, 354, 56-58. [CrossRef]

140. Lu, P.; Hsieh, Y.L. Multiwalled carbon nanotube (MWCNT) reinforced cellulose fibers by electrospinning. ACS Appl. Mater. Interface 2010, 2, 2413-2420. [CrossRef] [PubMed]

141. Ajayan, P.M.; Stephan, O.; Colliex, C.; Trauth, D. Aligned carbon nanotube arrays formed by cutting a polymer resin-nanotube composite. Science 1994, 265, 1212-1214. [CrossRef] [PubMed] 
142. Dillon, A.; Jones, K.M.; Bekkedahl, T.A.; Kiang, C.H.; Bethune, D.S.; Heben, M.J. Storage of hydrogen in single-walled carbon nanotubes. Nature 1997, 386, 377-379. [CrossRef]

143. Planeix, J.M.; Coustel, N.; Coq, B.; Brotons, V.; Kumbhar, P.S.; Dutartre, R.; Ajayan, P.M. Application of carbon nanotubes as supports in heterogeneous catalysis. J. Am. Chem. Soc. 1994, 116, 7935-7936. [CrossRef]

144. Bandyopadhyaya, R.; Nativ-Roth, E.; Regev, O.; Yerushalmi-Rozen, R. Stabilization of individual carbon nanotubes in aqueous solutions. Nano Lett. 2002, 2, 25-28. [CrossRef]

145. Kharissova, O.V.; Kharisov, B.I.; Casas Ortiz, E.G. Dispersion of carbon nanotubes in water and non-aqueous solvents. RSC Adv. 2013, 3, 24812-24852. [CrossRef]

146. Jung, D.H.; Ko, Y.K.; Jung, H.T. Aggregation behavior of chemically attached poly (ethylene glycol) to single-walled carbon nanotubes (SWNTs) ropes. Adv. Mater. Sci. Eng. C 2004, 24, 117-121. [CrossRef]

147. Lu, F.; Zhang, S.; Zheng, L. Dispersion of multi-walled carbon nanotubes (MWCNTs) by ionic liquid-based phosphonium surfactants in aqueous solution. J. Mol. Liq. 2012, 173, 42-46. [CrossRef]

148. Star, A.; Liu, Y.; Grant, K.; Ridvan, L.; Stoddart, J.F.; Steuerman, D.W.; Heath, J.R. Noncovalent side-wall functionalization of single-walled carbon nanotubes. Macromolecules 2003, 36, 553-560. [CrossRef]

149. Vaisman, L.; Wagner, H.D.; Marom, G. The role of surfactants in dispersion of carbon nanotubes. Adv. Colloid Interface Sci. 2006, 128, 37-46. [CrossRef] [PubMed]

150. Zhao, J.; Lu, J.P.; Han, J.; Yang, C.K. Noncovalent functionalization of carbon nanotubes by aromatic organic molecules. Appl. Phys. Lett. 2003, 82, 3746-3748. [CrossRef]

151. Chen, R.J.; Zhang, Y.; Wang, D.; Dai, H. Noncovalent sidewall functionalization of single-walled carbon nanotubes for protein immobilization. J. Am. Chem. Soc. 2001, 123, 3838-3839. [CrossRef] [PubMed]

152. Wang, H.; Zhou, W.; Ho, D.L.; Winey, K.I.; Fischer, J.E.; Glinka, C.J.; Hobbie, E.K. Dispersing single-walled carbon nanotubes with surfactants: A small angle neutron scattering study. Nano Lett. 2004, 4, 1789-1793. [CrossRef]

153. Wen, D.; Ding, Y. Effective thermal conductivity of aqueous suspensions of carbon nanotubes (carbon nanotube nanofluids). J. Thermophys. Heat Transf. 2004, 18, 481-485. [CrossRef]

154. Wusiman, K.; Jeong, H.; Tulugan, K.; Afrianto, H.; Chung, H. Thermal performance of multi-walled carbon nanotubes (MWCNTs) in aqueous suspensions with surfactants SDBS and SDS. Int. J. Heat Mass Transf. 2013, 41, 28-33. [CrossRef]

155. Nasiri, A.; Shariaty-Niasar, M.; Rashidi, A.; Amrollahi, A.; Khodafarin, R. Effect of dispersion method on thermal conductivity and stability of nanofluid. Exp. Therm. Fluid Sci. 2011, 35, 717-723. [CrossRef]

156. Hwang, Y.J.; Lee, J.K.; Lee, C.H.; Jung, Y.M.; Cheong, S.I.; Lee, C.G.; Jang, S.P. Stability and thermal conductivity characteristics of nanofluids. Thermochim. Acta 2007, 455, 70-74. [CrossRef]

157. Assael, M.J.; Metaxa, I.N.; Arvanitidis, J.; Christofilos, D.; Lioutas, C. Thermal conductivity enhancement in aqueous suspensions of carbon multi-walled and double-walled nanotubes in the presence of two different dispersants. Int. J. Thermophys. 2005, 26, 647-664. [CrossRef] 